\title{
An Enigmatic Tail of CD28 Signaling
}

\author{
Jonathan S. Boomer and Jonathan M. Green \\ Department of Internal Medicine, Washington University School of Medicine, St Louis, Missouri 63110 \\ Correspondence: jgreen@im.wustl.edu
}

\begin{abstract}
CD28 costimulation regulates a wide range of cellular processes, from proliferation and survival to promoting the differentiation of specialized T-cell subsets. Since first being identified over 20 years ago, CD28 has remained a subject of intense study because of its profound consequences on T cell function and its potential for therapeutic manipulation. In this review we highlight the signaling cascades initiated by the major signaling motifs in CD28, focusing on Pl-3 kinase-dependent and -independent pathways and how these are linked to specific cellular outcomes. Recent studies using gene targeted knockin mice have clarified the relative importance of these motifs on in vivo immune responses; however, much remains to be elucidated. Understanding the mechanism behind costimulation holds great potential for development of new clinically relevant reagents, a fact beginning to be realized with the advent of drugs that prevent CD28 ligation and signaling.
\end{abstract}

\section{OVERVIEW OF CD28-MEDIATED COSTIMULATION}

\begin{abstract}
A critical component of the immunological Aresponse to foreign protein is the activation of T lymphocytes. T-cell receptor (TCR) recognition of peptide loaded $\mathrm{MHC}$ molecules provides antigen specificity and initiates the required steps for T-cell activation, although additional signals are needed for complete T-cell activation. A two signal model for lymphocyte activation was first proposed by Bretscher and Cohn in 1970 as a mechanism for self:nonself discrimination in B cells (Bretscher and Cohn 1970) and was subsequently expanded to incorporate CD8 T-cell activation by Lafferty et al (Lafferty and Cunningham 1975). Using T-cell clones, Schwartz and Jenkins showed that engagement of the TCR by
\end{abstract}

peptide loaded MHC in the absence of other signals is insufficient to activate the $\mathrm{T}$ cell, and in fact may render it unresponsive to further antigenic stimulation, a condition termed anergy (Quill and Schwartz 1987; Mueller et al. 1989; Schwartz et al. 1989; Jenkins et al. 1990; Linsley and Ledbetter 1993). They further showed that provision of additional, non-MHC restricted signals provided by professional APC, resulted in the $\mathrm{T}$ cell becoming fully activated leading to clonal expansion and development of effector function. Thus, the two-signal model, where signal one is defined as the binding of peptide/MHC complexes and signal two refers to the additional, costimulatory signal(s), provided a potential mechanism for peripheral tolerance (June et al. 1990; June et al. 1994; Bluestone 1995). The most studied and well characterized costimulatory receptor/ligand

Editors: Lawrence E. Samelson and Andrey Shaw

Additional Perspectives on Immunoreceptor Signaling available at www.cshperspectives.org

Copyright (C) 2010 Cold Spring Harbor Laboratory Press; all rights reserved; doi: 10.1101/cshperspect.a002436

Cite this article as Cold Spring Harb Perspect Biol 2010;2:a002436 
complex is the CD28/B7 interaction (as reviewed in Rudd and Schneider 2003; Miller et al. 2009; Paterson et al. 2009; Rudd et al. 2009; Sharpe 2009).

CD28 was first identified by antibodies recognizing a $44 \mathrm{kDa}$ protein on the surface of human $\mathrm{T}$ cells that synergized with PHA in the induction of a proliferative response (Hansen et al. 1980; Gmünder and Lesslauer 1984). The cDNA was expression cloned in 1987 by Aruffo and Seed and shown to encode a $23 \mathrm{kD}$ type 1 transmembrane protein (Aruffo and Seed 1987). CD28 is expressed on the cell surface as a glycosylated, disulfide-linked homodimer (Aruffo and Seed 1987). In humans, CD28 is expressed on approximately $80 \%$ of CD $4+\mathrm{T}$ cells and $50 \%$ of CD8 $+\mathrm{T}$ cells and has been detected on plasma cells, neutrophils, and eosinophils, although the function in these latter cell types is unclear (Lee et al. 1990; Venuprasad et al. 2001; Woerly et al. 2002). In contrast to humans, in mouse $100 \%$ of both CD4 and CD8 T cells express CD28 (Gross et al. 1990).

Most important in the initial activation of naïve T cells, ligation of CD28 on CD4 + T cells has diverse and profound consequences. CD28 signaling increases the sensitivity of the $\mathrm{T}$ cell to antigen receptor engagement, and as a result proliferation is induced at otherwise submitogenic concentrations of antigen (Gmünder and Lesslauer 1984; Damle et al. 1988; Damle and Doyle 1989; Shahinian et al. 1993b; Bachmann et al. 1996; Bachmann et al. 1997). Cytokine production is greatly increased, most significantly IL-2. CD28 costimulation results in a 50 -fold increase in IL-2 secretion by both transcriptional and posttranscriptional regulation of expression (Lindsten et al. 1989; Fraser et al. 1991). Interestingly, under some conditions, this has been found to be resistant to suppression by cyclosporine, suggesting engagement of a novel signal transduction cascade (Thompson et al. 1989; Ledbetter et al. 1990). In addition, cell survival is enhanced by CD28 costimulation, in part by inducing expression of anti-apoptotic proteins including $\mathrm{Bcl}-\mathrm{X}_{\mathrm{L}}$ (Boise et al. 1995; Radvanyi et al. 1996; Sperling et al. 1996). Thus, by a variety of mechanisms,
CD28 mediated costimulation greatly enhances the $\mathrm{T}$ cells effector response to antigen

Whether CD28 can activate signaling independent of TCR engagement or function only in a TCR dependent manner has been controversial. The ability of certain "superagonistic" anti-CD28 antibodies to independently activate $\mathrm{T}$ cells suggests that in some circumstances CD28 can function in the absence of a TCR derived signal (Tacke et al. 1997; Luhder et al. 2003). Furthermore, microarray analysis of $\mathrm{T}$ cells stimulated only through CD28 supported TCR independent signaling; however, this effect appeared to be relatively short lived (Riley et al. 2002; Marinari et al. 2004). Importantly, the existence of both TCR dependent and independent pathways is not mutually exclusive, and it is likely that both are operative and important.

CD28 is the founding member of the immunoglobulin (Ig) family of costimulatory receptors (Hansen et al. 1980; Gmünder and Lesslauer 1984), that now includes the receptors: cytotoxic $\mathrm{T}$ lymphocyte-associated antigen 4 (CTLA-4, CD152) (Dariavach et al. 1988), inducible costimulator (ICOS) (Hutloff et al. 1999; Tezuka et al. 2000), programmed death receptor 1 (PD-1) (Ishida et al. 1992), and B- and T-lymphocyte attenuator (BTLA) (Watanabe et al. 2003). Although CD28 and CTLA-4 both bind the ligands B7-1 (CD80) and B7-2 (CD86) (Freeman et al. 1989; Balzano et al. 1992; Azuma et al. 1993; Freeman et al. 1993) and are located on human chromosome 2q33 (Naluai et al. 2000) (mouse chromosome 1 (Gross et al. 1990; Howard et al. 1991)), CTLA-4 forms bivalent homodimers between CD80 molecules which contributes to its higher affinity for CD80 (12 compared to a $200 \mathrm{nM}$ Kda value for CD28) (van der Merwe et al. 1997; Evans et al. 2005). CD28 and ICOS predominately enhance $\mathrm{T}$-cell activation unlike CTLA-4, PD-1 and BTLA which are inhibitory (Rudd and Schneider 2003; Miller et al. 2009; Paterson et al. 2009; Rudd et al. 2009; Sharpe 2009). This review will cover the diverse functions of the CD28-B7 interaction highlighting the complex signaling events that define CD28 function. 


\section{THE MOTIFS BEHIND CD28 SIGNALING}

The extracellular domain of CD28 binds to B7 proteins using a MYPPPY motif and this interaction initiates the costimulatory signal transduction cascade (Freeman et al. 1989; Balzano et al. 1992; Azuma et al. 1993; Freeman et al. 1993; Rudd and Schneider 2003). CD28 has a highly conserved, relatively short cytoplasmic tail (41 aa in human, 38 aa in mouse) that has no intrinsic enzymatic activity. However, several motifs have been identified including: four tyrosine residues, four serine and two threonine residues, two PxxP motifs, and two lysine residues each of which may be important in function (Rudd and Schneider 2003; Rudd et al. 2009). Phosphorylation of the tyrosine residues provides docking sites for src homology-2 (SH2) domain containing proteins whereas the proline-rich motifs can bind src homology-3 (SH3) domain containing proteins. The serine and threonine residues can also be phosphorylated and finally the lysine residues provide potential sites for ubiquitination. Interestingly CD28, CTLA-4, and ICOS share an YxxM motif (Rudd and Schneider 2003) a consensus binding site for the p85 subunit of the lipid kinase phosphatidyl-inositol 3-kinase (PI3K) (August and Dupont 1994; Pagès et al. 1994; Prasad et al. 1994). CD28 contains the sequence YMNM, where the Asn residue in the +2 position confers additional specificity for Grb2/
GADS binding (Songyang et al. 1993; Schneider et al. 1995b), whereas the methionine at the +3 position confers p85 specificity (Takeda et al. 2008). The ability to bind Grb2 is absent from both ICOS and CTLA-4, which may in part explain the signaling and functional differences between these coreceptors (Rudd and Schneider 2003; Rudd et al. 2009). Early work has shown that the cytoplasmic tail of CD28 is tyrosine phosphorylated presumably by the Src family kinases Fyn and Lck (Raab et al. 1995; King et al. 1997), as well as phosphorylated on serine/ threonine residues (Hutchcroft and Bierer 1994; Hutchcroft et al. 1996; Parry et al. 1997a). These events initiate specific protein-protein interactions and subsequent activation of downstream signaling cascades that define the costimulatory functions of CD28.

\section{Motif Specific Protein-Protein Interactions}

In the simplest format, CD28 signaling is initiated by activation of two dominant signaling cascades, one that requires phosphorylation of a tyrosine residue within the membrane proximal YMNM motif and subsequent binding of the $\mathrm{p} 85$ subunit of PI3K whereas another pathway is initiated by the more distal proline-rich regions (Rudd and Schneider 2003; Miller et al. 2009; Paterson et al. 2009; Rudd et al. 2009; Sharpe 2009) (Fig. 1). Each of these bind distinct sets of proteins, although there is

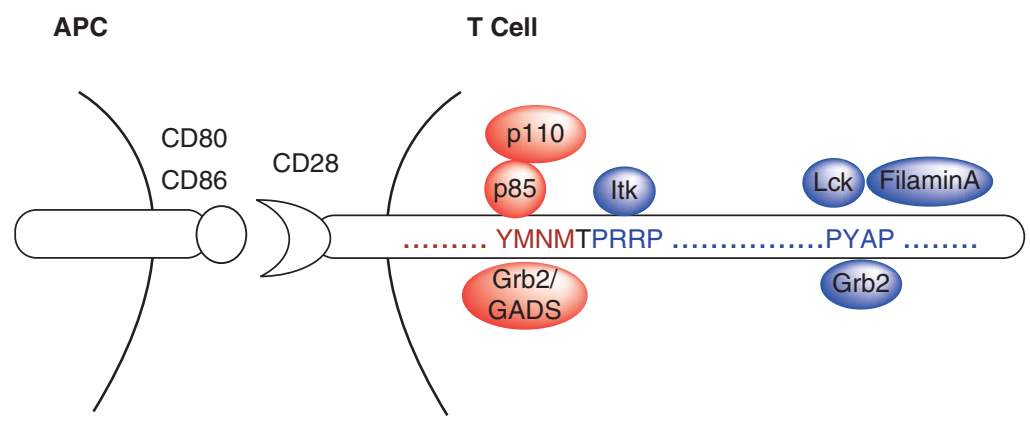

Figure 1. Motif specific protein:protein interactions with the cytoplasmic tail of CD28. Engagement of CD28 by CD80 or CD86 expressed on the antigen presenting cell (APC), initiates signal transduction cascades dependent on specific association of proteins with the cytoplasmic tail of CD28. The proximal YMNM motif when phosphorylated via Src family kinases binds the SH2 containing (indicated in red) proteins p85, a subunit of PI3K, and Grb2 or GADS via their SH2 domain. The distal proline-rich motifs bind the SH3 containing (indicated in blue) proteins Itk, at the sequence PRRP, and Grb2 (via its SH3 domain), filamin-A and Lck at the sequence PYAP. 
significant overlap and potential for interaction. The observation that PI3K activation was enhanced via CD28 signaling led to the discovery that the $\mathrm{p} 85$ subunit of PI3K directly binds the YMNM motif via an SH2 interaction following phosphorylation of the tyrosine residue (Pagès et al. 1994; Truitt et al. 1994; Cai et al. 1995; Raab et al. 1995). Although PI3K-dependent signaling is likely the major pathway initiated by the proximal motif, its relative importance in CD28 function has been highly controversial. Initial in vitro CD28 signaling results should be interpreted with caution as the Jurkat T-cell line lacks both the PTEN and SHIP-1 phosphatases that function to inactivate the products of PI3K; therefore, the threshold to fully activate PI3K is reduced (Shan et al. 2000; Freeburn et al. 2002). Other proteins that can bind this region include Grb2 and GADS via their SH2 domain (Raab et al. 1995; Schneider et al. 1995a; Kim et al. 1998; Ellis et al. 2000). Competition between Grb2, GADS and PI3K for binding to the YMNM motif may be important in determining downstream CD28-dependent signaling events

Signaling by the distal PYAP motif is likely initiated by binding and activation of the Src family kinase Lck (King et al. 1997; Holdorf et al. 1999) although Fyn, Grb2, and GADS (via their SH3 domains) can also bind this region (Okkenhaug and Rottapel 1998; Ellis et al. 2000). The association of IL-2-inducible T-cell kinase (Itk) directly with the proximal proline-rich region (PRRP) of CD28 via its SH3 domain (Marengere et al. 1997) has been shown; however, if this event requires PI3Kdependent production of D3-lipids remains poorly understood. The PYAP motif also associates with filamin-A, an actin binding protein that functions as a scaffold for lipid raft formation (Tavano et al. 2006).

The generation of two specific knockin mice by our laboratory, the CD28 Y170F and CD28 AYAA mice, has clarified the role(s) of these two motifs in CD28 function (Friend et al. 2006; Dodson et al. 2009). Mutation of the proximal YMNM motif, although abrogating $\mathrm{PI} 3 \mathrm{~K}$ binding and subsequent protein kinase $\mathrm{B}(\mathrm{PKB}) /$ Akt activation has no discernible in vivo effect (Dodson et al. 2009). On the other hand, mutation of the distal proline motif (PYAP) resulted in impaired CD28-dependent functions that included proliferation, IL-2 and other cytokine secretion, and adaptive immune system defects (Friend et al. 2006; Dodson et al. 2009). These data provide evidence that the distal proline motif initiates a critical, nonredundant signaling pathway required for CD28 function, whereas the proximal tyrosine based motif may be dispensable.

\section{PI3K-DEPENDENT SIGNALING PATHWAYS}

Activation of $\mathrm{PI} 3 \mathrm{~K}$ induces the production of the D3-lipids, phosphatidylinositol $(3,4)$ bisphosphate (PIP2) and phosphatidylinositol $(3,4,5)$-triphosphate (PIP3) where PIP3 is the main TCR/CD28 induced D3-lipid (Sasaki et al. 2000; Wang and Rudd 2008) (Fig. 2). These D3-lipids recruit pleckstrin homology $(\mathrm{PH})$ domain containing proteins including phosphoinositide-dependent kinase 1 (PDK1), $\mathrm{PKB} / \mathrm{Akt}$, and possibly Wiskott Aldrich Syndrome Protein (WASP), a sorting nexin (SNX9), Itk and Vav (Parry et al. 1997b; Costello et al. 2002; Harriague and Bismuth 2002; Badour et al. 2007). PKB can be phosphorylated and activated by PDK1 and is a particularly important PI3K-dependent effector protein in CD28 signaling (Vanhaesebroeck and Alessi 2000). Downstream targets of PKB are diverse and include glycogen synthase kinase 3 (GSK3), mTOR, cAMP responsive element binding protein-1 (CREB), Bcl-2 antagonist of cell death (BAD), Bcl-X $\mathrm{L}_{\mathrm{L}}$, FOXO family of transcription factors, and inhibitor of nuclear factor- $\kappa \mathrm{B}$ (IкB) (Vanhaesebroeck and Alessi 2000). Thus, the PI3K-dependent signaling pathway has the ability to regulate a diverse array of CD28 functions that include cell cycle progression, apoptosis, cellular metabolism, and IL-2 transcription.

\section{SIGNALING PATHWAYS INITIATED BY BINDING OF ADAPTOR PROTEINS}

In addition to the PI3K-dependent pathway, binding of adaptor proteins (i.e., Grb2 or GADS) to the proximal motif can initiate 


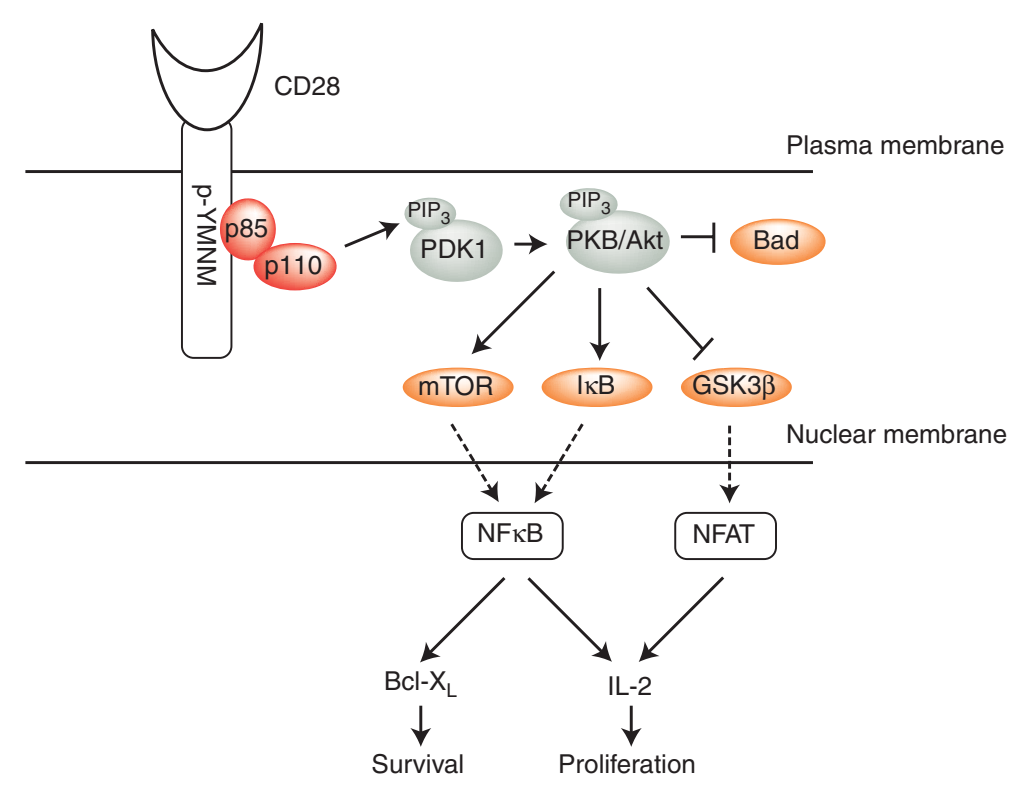

Figure 2. PI3K dependent signal pathway. Tyrosine phosphorylation of the YMNM motif via Src family kinases initiates the binding of the $\mathrm{p} 85$ subunit of PI3K. PI3K activity leads to the production of D-3 lipids, which recruit proteins via their pleckstrin homology domain $(\mathrm{PH})$, including PDK1 and PKB/Akt. Once PKB is phosphorylated by PDK1, PKB phosphorylates its downstream targets including mTOR, IкB, GSK3 $\beta$ and Bad. Active mTOR and I $\mathrm{B}$ result in increased NF- $\kappa \mathrm{B}$ transcriptional activity whereas the phosphorylation of Bad and GSK3 $\beta$ results in increased survival and NFAT transcriptional regulation, respectively. The activation of NF- $\kappa \mathrm{B}$ and NFAT (indicated by the dotted lines) induces the transcription of both Bcl- $\mathrm{X}_{\mathrm{L}}$, a prosurvival factor, and IL-2, an important T-cell cytokine required for proliferation as well as other genes.

signaling (Fig. 3). Grb2 recruits Son of Sevenless (Sos), a guanine nucleotide exchange factor and activator of GTPase p21 ${ }^{\text {ras }}$, and Vav, also an exchange factor (Schneider et al. 1995a; Collins et al. 1997; Bustelo 2000). A mechanism by which CD28 via Grb2 binding to the PxxP motif mediates JNK activation is plausible where Grb2 recruits Sos and Vav which in turn phosphorylate and activate Ras-related C3 botulinum toxin substrate (Rac1), PKC $\theta$ and cell division cycle 42 (CDC42) (Collins et al. 1997; Bustelo 2000). Rac1 and CDC42 activate the MEK4/MEK7 to MEKK1 signaling cascade culminating in JNK activation (Su et al. 1994). In support of this model, CD28 induces a GTP-RAC complex, possibly through the phosphorylation of Vav by ZAP-70 (Salojin et al. 1999), and activates MEKK1 in a Vav-dependent manner (Marinari et al. 2002). CD28-dependent activation of JNK (Su et al. 1994) is inhibited by mutant forms of Vav that lack functional GTP-GDP exchange activity and a dominant negative mutant of MEKK1 (Marinari et al. 2002; Wood et al. 2006). GADS potentially interacts with SLP76 and LAT in a signaling complex thereby providing CD28 a means to modulate TCR mediated signaling (Rudd and Schneider 2003; Rudd et al. 2009). Although these studies imply Grb2/GADS, Vav, PKC $\theta$, and downstream MAPK signaling are linked to the PxxP motifs in CD28, this cascade has yet to be fully defined.

\section{REGULATION OF IL-2 PRODUCTION BY CD28}

Transcriptional Regulation of the IL-2 Gene by CD28

The regulation of IL-2 by CD28 is complex involving both increased gene transcription and post-transcriptional stabilization of mRNA 
J.S. Boomer and J.M. Green
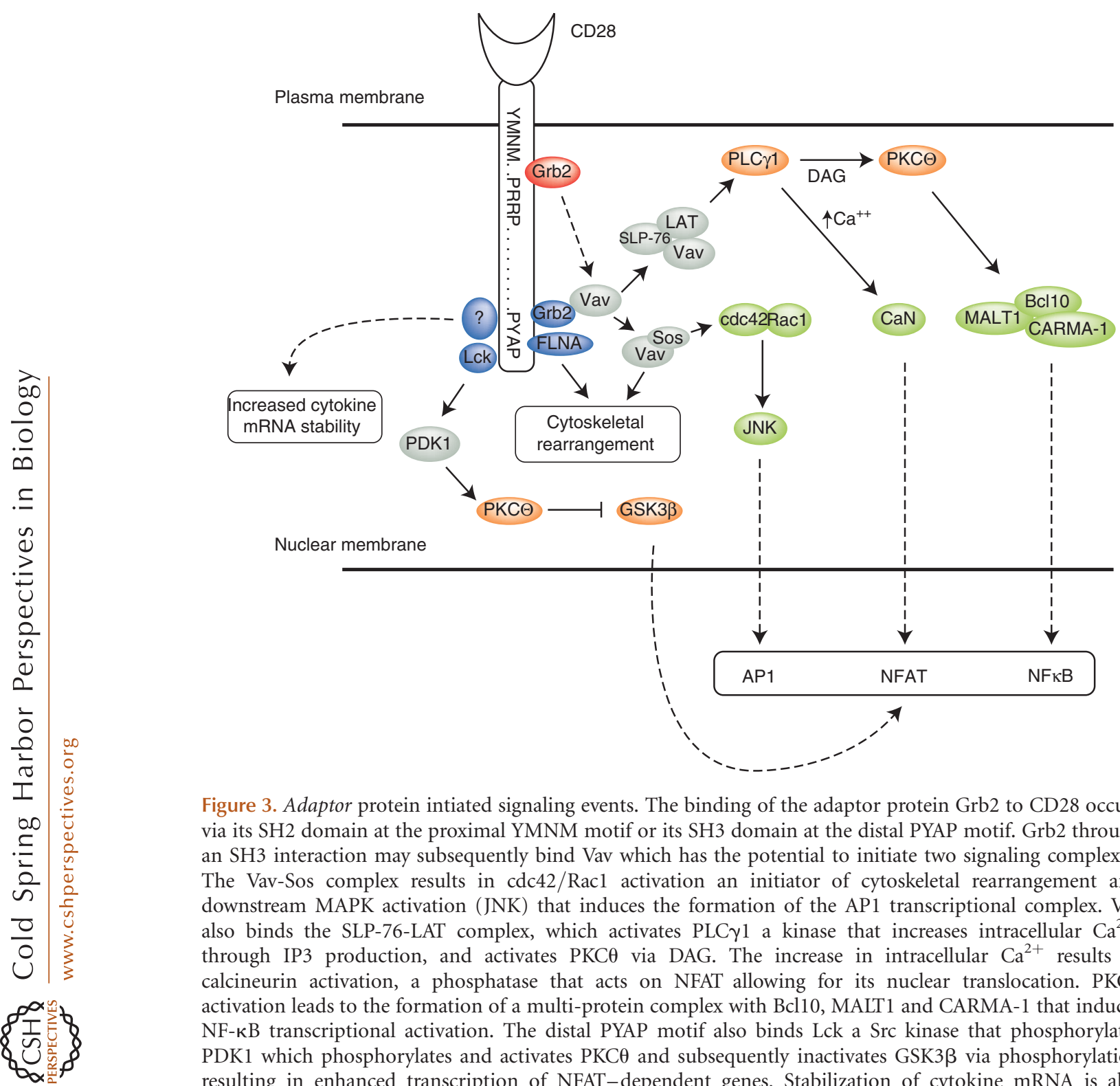

Figure 3. Adaptor protein intiated signaling events. The binding of the adaptor protein Grb2 to CD28 occurs via its $\mathrm{SH} 2$ domain at the proximal YMNM motif or its SH3 domain at the distal PYAP motif. Grb2 through an SH3 interaction may subsequently bind Vav which has the potential to initiate two signaling complexes. The Vav-Sos complex results in cdc42/Racl activation an initiator of cytoskeletal rearrangement and downstream MAPK activation (JNK) that induces the formation of the AP1 transcriptional complex. Vav also binds the SLP-76-LAT complex, which activates PLC $\gamma 1$ a kinase that increases intracellular $\mathrm{Ca}^{2+}$, through IP3 production, and activates PKC $\theta$ via DAG. The increase in intracellular $\mathrm{Ca}^{2+}$ results in calcineurin activation, a phosphatase that acts on NFAT allowing for its nuclear translocation. PKC $\theta$ activation leads to the formation of a multi-protein complex with Bcl10, MALT1 and CARMA-1 that induces NF- $\kappa \mathrm{B}$ transcriptional activation. The distal PYAP motif also binds Lck a Src kinase that phosphorylates PDK1 which phosphorylates and activates PKC $\theta$ and subsequently inactivates GSK3 $\beta$ via phosphorylation resulting in enhanced transcription of NFAT-dependent genes. Stabilization of cytokine mRNA is also dependent on signals originating at the PYAP through a mechanism that may involve Lck binding (indicated via the dotted arrow) or an unknown protein whereas cytoskeletal rearrangement at the PYAP motif is filamin-A (FLNA) dependent.

(Lindsten et al. 1989; Bohjanen et al. 1992). The IL-2 promoter has binding elements for members of the NFAT, NF- $\kappa$ B, Oct-1, and AP-1 (c-fos/Jun) families of transcription factors and $\mathrm{CD} 28$ regulates the expression and activity of NFAT, NF-кB, and AP-1 (Fraser et al. 1991;
Granelli-Piperno and Nolan 1991; Shapiro et al. 1997; Miller et al. 2009). Research pioneered by the Weiss laboratory identified a specific region in the IL-2 promoter, termed the CD28response element (CD28RE) that binds transcription factors in a CD28-dependent manner 
thus providing a site for signal integration (Fraser et al. 1991; Shapiro et al. 1997). Analyses of the CD28RE/AP-1 complex determined that CD28 signaling activated both IкB $\alpha$ and IкB $\beta$ resulting in increased transcription of IL-2, which was inhibited by dominant negative mutants of these ІкB proteins (Lai and Tan 1994; Harhaj et al. 1996; Harhaj and Sun 1998; Zhou et al. 2002). The phosphorylation of the ІкB complex, which targets ІкB for degradation through ubiquitination, via upstream serine/threonine kinases called the ІкB kinases (IKKs), results in NF- $\mathrm{B}$ translocation to the nucleus (Lai and Tan 1994; Harhaj et al. 1996; Harhaj and Sun 1998). CD28-dependent IKK activation was inhibited by a dominant negative MEKK1 and IKK deficient cells have defective IL-2 production implicating CD28 as an upstream mediator of the IKK complex and NF- $\kappa \mathrm{B}$ activation (Harhaj et al. 2000; Tuosto et al. 2000). Through a mutational screen, mice identified as defective in antigen receptor activation of JNK and NF- $\kappa \mathrm{B}$ were subsequently determined to also be defective in caspase recruitment domain-containing membrane associated guanylate kinase protein-1 (CARMA-1) activation (Jun et al. 2003). CARMA-1 binds Bcl10 via CARD-CARD binding domains and activation of CARMA-1 is enhanced by PKCO phosphorylation (Gaide et al. 2002; Takeda et al. 2008). Bcl10 deficient T cells also show impaired NF- $\mathrm{KB}$ activation; therefore, a CD28-dependent signaling cascade can be predicted for $\mathrm{NF}-\kappa \mathrm{B}$ that includes $\mathrm{PKC} \theta$, Bcl10 and CARMA-1 proteins (Gaide et al. 2002; Takeda et al. 2008). The series of events that initiate this complex is not well understood, but the oligimerization of the CARMA-1 protein through its coiled-coil domain (CC2) and its localization via its CC1 domain are involved (Tanner et al. 2007) along with a lysine residue at 808 of CARMA-1 (Wang et al. 2004).

Analyses using CD28 deficient T cells determined that CD28 is required for proper segregation of PKC $\theta$ into the immunological synapse and the failure to localize $\mathrm{PKC} \theta$ correctly results in poor activation of NF- $\mathrm{KB}$ and IL-2 gene transcription (Huang et al. 2002; Sanchez-Lockhart et al. 2004; Sanchez-Lockhart and Miller 2006). Mice or $\mathrm{T}$ cell lines deficient in PKC $\theta$ have a pronounced defect in NF- $\mathrm{B}$ activation through TCR-CD28 signals (Sun et al. 2000; Matsumoto et al. 2005). In Jurkat T cells Vav has been shown to bind PKC $\theta$ and acts synergistically to enhance CD28-dependent activation of NF- $\mathrm{B}$ (Coudronniere et al. 2000; Dienz et al. 2000; Hehner et al. 2000a; Hehner et al. 2000b; Villalba et al. 2000a). Results indicate the CARMA-1, Bcl10, and mucosa-associated lymphoid tissue (MALT) lymphoma translocation gene 1 (MALT1) complex is dependent on CD28-dependent PKCO translocation and activation, possibly through Vav and Grb2, to regulate NF- $\kappa \mathrm{B}$ activation (Wang et al. 2002; Hara et al. 2003; Jun et al. 2003; Wang et al. 2004; Tanner et al. 2007). CD28 activation of NF- $\kappa$ B may involve RIP-2, a CARD containing adaptor also called CARDIAK or RICK, as RIP-2 deficient T cells have impaired IL-2 production, proliferation, and NF- $\kappa \mathrm{B}$ transcription (Kobayashi et al. 2002). CD28 mediated activation of NF- $\mathrm{KB}$ may include the role of PKB, NIK, and Cot; however, this remains unclear as these experiments used overexpression of mutant proteins or resulted in partial inhibition of CD28 functions (Kane et al. 1999; Lin et al. 1999; Hehner et al. 2000b; Yamada et al. 2000; Bauer et al. 2001).

Regulation of NFAT by CD28 is another costimulatory pathway that augments IL-2 expression (Fraser et al. 1991). TCR and CD28dependent signaling pathways cooperate in the activation of PLC $\gamma$-1 leading to increased intracellular calcium levels, PKC phosphorylation and activation of calcineurin $\left(\mathrm{Ca}^{2+}\right.$-dependent Ser/Thr phosphatase, CaN), which then dephosphorylates NFAT enhancing its nuclear translocation (Fraser et al. 1991). The immunosuppressant drugs cyclosporine and tacrolimus block CaN activation and thereby prevent NFAT translocation (Fraser et al. 1991). In contrast, CD28 derived signals induce the phosphorylation and inactivation of GSK3 $\beta$, a kinase that promotes the nuclear export of NFAT (Diehn et al. 2002; Pan et al. 2007). By this mechanism, CD28 leads to NFAT nuclear trapping and increased transcription of NFAT-dependent genes, 
including IL-2 (Diehn et al. 2002; Pan et al. 2007).

Postranscriptional Regulation of IL-2 mRNA Expression

In addition to transcriptional control of the IL-2 gene, CD28 regulates the stability of IL-2 and other cytokine mRNA (Lindsten et al. 1989; Miller et al. 2009). Specific AUUA sequences in the $3^{\prime}$ untranslated region destabilize the message (Bohjanen et al. 1992). Briefly, there are two general models of mRNA stability 1 ) microRNA and 2) AU-rich elements (ARE) within the $3^{\prime}$ UTR of the mRNA that affect degradation of the RNA especially that of cytokine genes including IL-2 (Lindsten et al. 1989). In unstimulated cells AU-binding proteins bind the $3^{\prime}$ UTR and recruit a multicomponent exosome that deadenylates and digests the $3^{\prime}$ UTR of the mRNA via exonucleases (Ogilvie et al. 2005). T-cell stimulation induces TTP activation, an AU-binding protein, and subsequent binding to the ARE within the $3^{\prime}$ UTR of IL-2 mRNA that induces degradation (Ogilvie et al. 2005). The absence of TTP results in increased IL-2 expression after T-cell activation (Ogilvie et al. 2005). To counter TTP induced degradation, a CD28-dependent mechanism may require $\mathrm{HuR}$ translocation to the cytoplasm (Seko et al. 2004) and/or elements of MAPK activation (i.e., JNK and p38) (Chen et al. 1998; Winzen et al. 1999; Chen et al. 2000). As CD28 regulates JNK activation (Su et al. 1994; Marinari et al. 2002; Wood et al. 2006), YB-1 and nucleolin, JNK induced proteins, stabilize the IL-2 transcript at the $5^{\prime}$ end; however, these proteins are not sufficient and may require another protein that binds to the $3^{\prime}$ UTR (Chen et al. 2000). One possible candidate, NF90, a transcription factor associated with NFAT and IL-2 activation (Corthesy and Kao 1994), has been shown to compete with TTP for binding at the ARE of IL-2 mRNA (Shim et al. 2002). NF90 knockout T cells have decreased IL-2 secretion but whether this effect is on the regulation of IL-2 transcription or mRNA stability, as well as, how CD28 signaling affects NF90 function is unclear (Shi et al. 2007). T-cell activation shuttles NF90 from the nucleus to the cytoplasm that dissociates TTP from the ARE and results in IL-2 mRNA stabilization (Shim et al. 2002; Shi et al. 2007).

Attempts to dissect the signaling pathway from CD28 to IL-2 using a mutational approach have yielded inconsistent results. Early experiments in Jurkat cells showed an association of PI3K with CD28 but the dependency of IL-2 secretion on this association were conflicting (Stein et al. 1994; Truitt et al. 1994; Crooks et al. 1995; Lu et al. 1995; Truitt et al. 1996; Sadra et al. 1999). A role for the YMNM motif in IL-2 secretion was suggested using murine cell lines but whether this was mediated through Grb2 or PI3K was not clear (Pagès et al. 1994; Cai et al. 1995; Kim et al. 1998; Watanabe et al. 2006). The role of the YMNM motif in IL-2 secretion remained unclear from studies in transgenic mice or retroviral reconstitution on the CD28-deficient background (Burr et al. 2001b; Harada et al. 2001; Okkenhaug et al. 2001; Andres et al. 2004b). These data showed either no effect on proliferation and IL-2 secretion (Okkenhaug et al. 2001; Andres et al. 2004b), a partial inhibition (Burr et al. 2001b), or inhibition of proliferation and IL-2 secretion at early time points (Harada et al. 2001). A caveat of these experiments is that $\mathrm{CD} 28$ expression is not under endogenous control but that of a heterologous promoter.

Recent data has supported the PYAP motif as the dominant signaling motif determining the net output of IL-2 following CD28 costimulation. In a retroviral reconstitution system, the proline to alanine mutation within the PYAP motif resulted in either decreased CD28-dependent proliferation and IL-2 production (Burr et al. 2001b) or no effect unless this mutation is combined with the tyrosine mutation in the YMNM motif (Andres et al. 2004b). In transgenic mice, the PYAP motif had impaired CD28-dependent proliferation whereas the Itk binding proline motif (PRRP) did not (Gogishvili et al. 2008). Interestingly, in a PI3K mutant mouse $\left(\mathrm{p} 110 \delta^{\mathrm{D} 910 \mathrm{~A} / \mathrm{D} 910 \mathrm{~A}}\right)$ CD28-dependent proliferation was maintained whereas Vav deficient primary $\mathrm{T}$ cells had defective proliferation (Gogishvili et al. 2008). These results predict 
Signaling through the CD28 receptor

that the PYAP motif mediates CD28-dependent proliferation through Vav and Lck independently of PI3K, although the role of Grb2 or GADS (Watanabe et al. 2006) was not directly addressed.

We directly tested the relative importance of the YMNM and the PYAP motifs in regulating CD28-dependent IL-2 production using gene targeted knockin mice. This approach benefits from the study of truly naïve $\mathrm{T}$ cells in which CD28 expression is controlled by endogenous elements. Under these conditions the PYAP motif has a critical role in CD28 mediated proliferation and IL-2 secretion (Friend et al. 2006; Dodson et al. 2009). Importantly, these studies also showed that CD28 expression level is an important determinant of the outcome of engagement as mice with a single AYAA allele had greater impairment in both proliferation and IL-2 secretion than mice with two AYAA alleles. In contrast, the Y170F mutation had little appreciable effect independent of gene dosage (Dodson et al. 2009). There is segregation of transcriptional control of IL-2 expression and regulation of mRNA stability by the YMNM and PYAP motifs. The Y170F mutation impairs IL-2 transcription but has little effect on net IL-2 secretion and no effect on mRNA stability whereas mutation of the PYAP motif has the reciprocal effect (Sanchez-Lockhart et al. 2004; Miller et al. 2009) (X. Wang, J. Green and J. Miller, unpublished data). The PYAP motif can mediate Grb2 binding and downstream JNK activation; therefore, these data give credence to the theory that CD28-dependent JNK activation is the dominant pathway resulting in IL-2 mRNA stability.

The CD28 knockin mice also provided an opportunity for us to directly examine components of the signaling cascade leading to IL-2 production in naïve, primary T cells. Previous studies showed that the YMNM motif was required for CD28-dependent activation of $\mathrm{PKB}$, which in turn led to phosphorylation and inactivation of GSK3 $\beta$ resulting in enhanced IL-2 gene transcription (Ohteki et al. 2000; Appleman et al. 2002; Diehn et al. 2002; Wood et al. 2006). However, data from the knockin mice showed the phosphorylation of both PKC $\theta$ and GSK3 $\beta$ were dependent on the PYAP and not the YMNM motif (Dodson et al. 2009). An alternative mechanism of the phosphorylation of GSK3 $\beta$ has been proposed where PKC isoforms directly phosphorylate GSK3 $\beta$ possibly through Vav or PDK1 (Lee et al. 2005) independent of PKB (Goode et al. 1992; Fang et al. 2002; Vilimek and Duronio 2006), a model supported by the knockin data.

\section{CD28 SIGNALING AND THE IMMUNOLOGICAL SYNAPSE}

The organization of specific proteins within the contact site of the APC and T cell during T-cell activation is referred to as the immunological synapse (Grakoui et al. 1999; Dustin and Chan 2000; van der Merwe 2002). Proteins segregate into supramolecular activation clusters (SMAC), which contain three distinct domains: the CSMAC (" $c$ " indicates central), enriched in TCR, CD4, CD28, and signaling components such as PKC $\theta$ and Lck, the pSMAC ("p" indicates peripheral), enriched in LFA-1 and other cytoskeletal components and an outer region that contains mostly CD45 (Grakoui et al. 1999; Bromley et al. 2001; Bunnell et al. 2002; Freiberg et al. 2002). Initially, TCR and CD4 form small microclusters that also contain CD28 within the cSMAC whereas LFA-1 moves into the pSMAC (Grakoui et al. 1999; Krummel et al. 2000; Andres et al. 2004a). Although how the activation of Lck and its role in CD28 signaling is poorly understood, the colocalization of CD45, a phosphatase that activates Lck by removing an inhibitory phosphate (Y505), with CD4 associated Lck and CD28 in these microclusters provides a possible model of Lck activation and association with CD28 (Johnson et al. 2000; Freiberg et al. 2002).

CD28 is required for the localization of PKC $\theta$ to the immunologic synapse (Monks et al. 1998; Bromley et al. 2001; Andres et al. 2004a). Mutational analysis mapped this requirement to the YMNM motif, suggesting a PI3K-dependent mechanism (Sanchez-Lockhart et al. 2004; Sanchez-Lockhart and Miller 2006; Yokosuka et al. 2008). In recent 
experiments, the ability of $\mathrm{CD} 28$ to recruit PKC $\theta$ to the immunological synapse was subsequently determined to be independent of PIP3 generation (Garcon et al. 2008). Interestingly PKC $\theta$ colocalizes with filamin-A, and when filamin-A is knocked down via siRNA, PKCO activity, as well as, NF- $\mathrm{KB}$, NFAT/AP-1, and IL-2 transcription are reduced (Hayashi and Altman 2006). As CD28 has the ability to modulate the cytoskeletal components, Rho (Kaga et al. 1998) SLP76, Rac1 (Michel et al. 2000; Raab et al. 2001), and PKC (Villalba et al. 2000a) in a Vav-dependent mechanism (Villalba et al. 2000b) and Vav has been shown to enable the TCR/CD3 complex to cluster (Fischer et al. 1998; Holsinger et al. 1998; Krawczyk et al. 2002), a CD28-dependent molecular signaling scaffold may be postulated at the immunological synapse. CD28 is tethered to the lipid raft via binding of filamin-A (Tavano et al. 2006) where CD28, through the YMNM motif, recruits PKCA via PI3K activation (SanchezLockhart et al. 2008). Thus, CD28 actin rearrangement functions through the binding of filamin-A, the downstream activation of Vav and PKC $\theta$ and the Vav effectors CDC42 and Rho-GTPases (Tavano et al. 2006). These data predict the movement of $\mathrm{CD} 28$ to the immunological synapse occurs before the majority of signaling events, through its PYAP motif, and is critical for CD28's ability to function.

After the PYAP motif has recruited CD28 to the immunological synapse, the binding of PI3K to the YMNM motif also modulates CD28 receptor mediated endocytosis. CD28 undergoes internalization, an event that requires the YMNM motif and binding of PI3K, which results in degradation via the lysosome or a recycling back to the cell surface (Cefai et al. 1998). CD28 internalization also requires the recruitment of WASP, via its SH3 domain, and a sorting nexin (SNX9) (Snapper and Rosen 1999; Badour et al. 2007). An SNX9 mutant that lacks the phagocyte oxidase homology (PX) domain that interacts with the p85 subunit of PI3K and PIP3 failed to induce CD28 internalization and NFAT transcription, whereas the overexpression of SNX9 increased these processes (Badour et al. 2007). These results indicate that
CD28 recruitment and signaling is functionally linked to the active signaling environment of the immunological synapse.

\section{CD28 ENHANCES T-CELL SURVIVAL}

A major consequence of CD28 signaling is protection from cell death (Boise et al. 1995; Noel et al. 1996; Radvanyi et al. 1996; Sperling et al. 1996). The two dominant pathways of apoptosis in $\mathrm{T}$ cells are (1) receptor mediated (i.e., TNF family) or (2) mitochondrial-associated proteins (i.e., the Bcl family) both of which are modulated via CD28 signaling (Rudd et al. 2009). CD28 costimulation prevents activation induced cell death (AICD) by inhibiting the expression of CD95L expression (cis mediated death) on the $\mathrm{T}$ cell and by decreasing the formation of the death inducing signaling complex (DISC) (Kirchhoff et al. 2000). CD28 stimulation increases the protein expression of c-FLIPs which compete with procaspase 8 for binding to the death domains of CD95 and FADD thereby preventing the conversion of procaspase 8 to active caspase 8 and the induction of cell death (Kirchhoff et al. 2000). CD28-deficient cells are more sensitive to Fas-mediated cell death, which could be reversed by the overexpression of $\mathrm{PKB}$ (Jones et al. 2002). The overexpression of PKB prevented the binding and downstream conversion of procaspase 8 to caspase 8 through inhibition of the DISC complex (Jones et al. 2002). CD28 also enhances targets of glycolysis, including Glut1 expression and glucose uptake, all required for increased metabolism during cellular proliferation through the activation of $\mathrm{PKB}$ (Frauwirth et al. 2002).

$\mathrm{CD} 28$ stimulation also induces the up-regulation of antiapoptotic factors including $\mathrm{Bcl}-\mathrm{X}_{\mathrm{L}}$ (Boise et al. 1995). The overexpression of Bcl- $X_{L}$ in CD28-deficient mice restores cellular survival but not proliferation (Dahl et al. 2000); thereby, separating these two CD28-dependent functions. $\mathrm{Bcl}-\mathrm{X}_{\mathrm{L}}$, an NF- $\mathrm{\kappa B}$ inducible gene, requires CD28-dependent IKK activation through the activation of PKCA and formation of the CARMA-1, Bcl10, and MALT1 complex (Wang et al. 2002; Hara et al. 2003; Jun et al. 2003; 
Wang et al. 2004; Tanner et al. 2007; Takeda et al. 2008). CD28-deficient mice reconstituted with a disrupted YMNM motif failed to induce Bcl- $\mathrm{X}_{\mathrm{L}}$ whereas CD28-deficient mice reconstituted with disrupted proline rich motifs of CD28 retained the capacity to induce $\mathrm{Bcl}-\mathrm{X}_{\mathrm{L}}$ (Burr et al. 2001b; Harada et al. 2001; Okkenhaug et al. 2001). The overexpression of PKB led to constitutively elevated amounts of $\mathrm{Bcl}-\mathrm{X}_{\mathrm{L}}$ protein and inhibited FAS mediated apoptosis (Jones et al. 2000; Jones et al. 2002). These data suggested a central role for the YMNM motif, via $\mathrm{PKB}$ activation, in the regulation of cell survival by CD28. These results held true until the generation and analysis of CD28 knockin mice, which surprisingly indicated that neither mutation in the YMNM or PYAP motifs alone prevented CD28-dependent up-regulation of Bcl- $\mathrm{X}_{\mathrm{L}}$ (Dodson et al. 2009). However, the expression of $\mathrm{Bcl}-\mathrm{X}_{\mathrm{L}}$ is dependent on both PKC $\theta$ and NF- $\kappa B$ activation, events that are regulated by $\mathrm{CD} 28$ and may not be exclusively downstream of the YMNM motif (Khoshnan et al. 2000; Marinari et al. 2004; Li et al. 2005; Manicassamy et al. 2006).

\section{CD28 REGULATES T-CELL SUBTYPE DEVELOPMENT AND DIFFERENTIATION}

Although the peripheral T-cell repertoire is not markedly altered in the absence of CD28, a role in negative selection has been suggested (Shahinian et al. 1993b; Lucas et al. 1995; Sperling et al. 1996; Noel et al. 1998). However a more dramatic phenotype has been uncovered with the identification of regulatory $\mathrm{T}$ cells (Tregs) (Boden et al. 2003; Tang et al. 2003; Tai et al. 2005; Guo et al. 2008). CD28-deficient mice have drastically reduced numbers of thymically derived Tregs (Salomon et al. 2000; Tang et al. 2003; Lohr et al. 2004; Tai et al. 2005). CD28 could contribute to Treg development enhancing IL-2 production (Guo et al. 2008) or by a cell intrinsic mechanism (Tai et al. 2005; Tao et al. 2005). However, the failure of wild-type cells to support the generation of CD28-deficient Tregs suggests that exogenous IL-2 is not sufficient in the absence of other CD28- dependent signals (Tai et al. 2005). Additional data recently obtained using the knockin mice supports that CD28, partially via the distal carboxy-terminal proline motif, provides an intrinsic signal necessary for the generation of cytokine responsive Treg precursors ( $\mathrm{C}$ Lio, $\mathrm{C}$ Hsieh, and J Green, unpublished data).

As the differentiation of $\mathrm{T}$ cells into distinctive populations ( $\mathrm{TH} 0, \mathrm{TFh}, \mathrm{TH} 1, \mathrm{TH} 2$, and TH17) are defined in part by their cytokine secretion profiles, a role for CD28 in the generation and maintenance of these populations has been implicated. Although CD28 regulates multiple cytokines, it is neither absolutely required nor sufficient for the generation of any distinct T-cell subset. CD28 is important for TH2 generation but not the secretion of $\mathrm{TH} 2$ cytokines (King et al. 1995; Rulifson et al. 1997); however, $\mathrm{TH} 1$ generation does not require CD28 but the secretion of IL-2 by these cells requires CD28 (Shahinian et al. 1993a; Lucas et al. 1995; Villegas et al. 1999). Transgenic overexpression of $\mathrm{PKB}$ in CD28-deficient mice restored the production of IL- 2 and IFN- $\gamma$ but not IL- 4 and IL- 5 the cytokines required for the generation of TH2 cells (Kane et al. 2001). CD28-deficient mice show a defect in IL-4 production on receptor stimulation, which is partially restored by the overexpression of PDK1 (Andres et al. 2004b; Nirula et al. 2006). Although PDK1 is an upstream activator of $\mathrm{PKB}$, in this case PDK1 was determined to be dependent on PKA and NFAT (Nirula et al. 2006). CD28-deficient and IL-4 deficient mice fail to induce germinal center formation and upregulation of CD40L in an Ova model of stimulation (Reiter and Pfeffer 2002). Interestingly, AYAA knockin mice also have defects in IL-4 production, germinal center formation, and decreased activation of PDK1 (Friend et al. 2006; Dodson et al. 2009). These data illustrate the complex role of the YMNM and PYAP motifs in the activation of $\mathrm{PKB}$ and $\mathrm{PKA}$ in TH2 type T cells and in the secondary immune response.

The development of a specialized cell type called NKT cells, as characterized by the expression of both a T-cell marker, invariant TCR (V $\alpha 14-J \beta 18)$, and an NK marker (NK1.1) that respond to glycolipid $\alpha$-galactosylceramide 
when presented by CD1d, is also dependent on CD28 signals (Williams et al. 2008). Through the use of CD28-deficient and B7-deficient mice, a distinctive role of $\mathrm{CD} 28$ in the thymic generation of these NKT cells was identified, as the absence of either CD28 or its ligand B7 resulted in severely decreased numbers of NKT cells (Williams et al. 2008). Paradoxically, the overexpression of B71 in the thymus of transgenic mice also resulted in decreased NKT cells (Williams et al. 2008). These results suggest that not only the presence of CD28 but the strength of signaling through CD28 coordinate in the development and differentiation of cell types.

\section{THE ROLE OF CD28 COSTIMULATION IN DISEASE}

Perhaps surprisingly, mutations in CD28 have not been identified as the genetic basis for any human disease. However, mouse models of disease have been shown to depend on CD28 function. The use of CD28- and B7-deficient cells has implicated this pathway in the generation of a TH2 response required for the destruction of islet cells (autoimmune diabetes in the NOD mouse model) (Lenschow et al. 1996) and in the activation of newly recruited $\mathrm{T}$ cells responsible for epitope spreading (relapsing EAE in the EAE mouse model) (Miller et al. 1995). CD28 has been shown to be required in a model of allergic airway inflammation (Harris et al. 1997a; Harris et al. 1997b; Keane-Myers et al. 1997; Mathur et al. 1999; Burr et al. 2001a). A variety of transplantation studies showed that a lack of CD28 could prolong graft acceptance, but in most cases the organs were eventually rejected (Turka et al. 1992; Sayegh and Turka 1998; Harada et al. 2001). However, when combined with blockade of CD40:CD40L interactions, indefinite graft acceptance was achieved (Larsen et al. 1996).

Examination of the role for the specific motifs of CD28 in disease models are limited; however, the PYAP motif was important in a model of autoimmune disease using CTLA-4deficient mice (Tai et al. 2007), a functional
YMNM motif is needed to generate a graft versus host response (Harada et al. 2001) whereas disease severity in experimental allergic encephalomyelitis is reduced in CD28-deficient mice and the CD28-AYAA knockin mice, but not the CD28-Y170F knockin mice (Friend et al. 2006; Dodson et al. 2009). In the absence of CD28 or in the CD28-AYAA knockin mice, antibody production and germinal center formation is markedly reduced (Friend et al. 2006; Dodson et al. 2009). Thus, in a number of model systems, CD28 plays a critical role.

An understanding of costimulation, and the mechanism by which it regulates immune responses provides new avenues for the development of therapeutics. As CD28 decreases the threshold required to activate naïve $\mathrm{T}$ cells, as well as increasing the survival of activated $\mathrm{T}$ cells, one can envision development of drugs that either potentiate or down-regulate an immune response. Although global inhibition of CD28 function would be anticipated to profoundly inhibit T-cell function, more specific targeting of specific regions of the extracellular or intracellular regions of $\mathrm{CD} 28$ (i.e., the B7 binding domain or the signaling motifs YMNM or PYAP) via antibodies, small molecule mimetics or siRNAs could potentially alter some aspects of CD28 effects whereas leaving others intact. This is beginning to be realized with the approval and marketing of a humanized version of CTLA4Ig (abatacept, Orencia $^{\mathrm{TM}}$ ) for the treatment of rheumatoid arthritis in adults and Stills disease in children (Genovese et al. 2005) and is being explored for other conditions (Linsley and Nadler 2009; Podojil and Miller 2009). Second generation agents have shown promise in the prevention of transplant rejection (Vincenti et al. 2005). The potential for the manipulation of costimulatory signals as an approach for cancer immunotherapy is currently an area of active study (Waldmann and Morris 2006). Although the exact mechanism of action of CTLA4Ig and related compounds is not fully understood these agents have promise for providing greater specificity in the manipulation of the immune response with less toxicity than many currently used drugs. 


\section{ACKNOWLEDGMENTS}

Supported in part by National Institutes of Health (NIH) grant HL062683 to JMG. We thank J. Miller, X. Wang, C. Lio and Chyi-Song Hsieh for willingness to share unpublished data.

\section{REFERENCES}

Andres PG, Howland KC, Dresnek D, Edmondson S, Abbas AK, Krummel MF. 2004a. CD28 signals in the immature immunological synapse. J Immunol 172: 5880-5886.

Andres PG, Howland KC, Nirula A, Kane LP, Barron L, Dresnek D, Sadra A, Imboden J, Weiss A, Abbas AK. 2004b. Distinct regions in the CD28 cytoplasmic domain are required for $\mathrm{T}$ helper type 2 differentiation. Nat Immunol 5: 435-442.

Appleman LJ, van Puijenbroek AA, Shu KM, Nadler LM, Boussiotis VA. 2002. CD28 costimulation mediates down-regulation of p27kip1 and cell cycle progression by activation of the PI3K/PKB signaling pathway in primary human T cells. J Immunol 168: 2729-2736.

Aruffo A, Seed B. 1987. Molecular cloning of a CD28 cDNA by a high-efficiency COS cell expression system. Proc Nath Acad Sci 84: 8573-8577.

August A, Dupont B. 1994. CD28 of T lymphocytes associates with phosphatidylinositol 3-kinase. Int Immunol 6: 769-774.

Azuma M, Ito D, Yagita H, Okumura K, Phillips JH, Lanier LL, Somoza C. 1993. B70 antigen is a second ligand for CTLA-4 and CD28. Nature 366: 76-79.

Bachmann MF, McKall-Faienza K, Schmits R, Bouchard D, Beach J, Speiser DE, Mak TW, Ohashi PS. 1997. Distinct roles for LFA-1 and CD28 during the activation of naive T cells: Adhesion versus costimulation. Immunity 7: 549-557.

Bachmann MF, Sebzda E, Kündig TM, Shahinian A, Speiser DE, Mak TW, Ohashi PS. 1996. T cell responses are governed by avidity and co-stimulatory thresholds. Eur J Immunol 26: 2017-2022.

Badour K, McGavin MK, Zhang J, Freeman S, Vieira C, Filipp D, Julius M, Mills GB, Siminovitch KA. 2007. Interaction of the Wiskott-Aldrich syndrome protein with sorting nexin 9 is required for CD28 endocytosis and cosignaling in T cells. Proc Natl Acad Sci 104: $1593-1598$.

Balzano C, Buonavista N, Rouvier E, Golstein P. 1992. CTLA-4 and CD28: similar proteins, neighbouring genes. Int J Cancer Suppl 7: 28-32.

Bauer B, Krumbock N, Fresser F, Hochholdinger F, Spitaler M, Simm A, Uberall F, Schraven B, Baier G. 2001. Complex Formation and Cooperation of Protein Kinase C $\theta$ and Akt1/Protein Kinase B $\alpha$ in the NF-к B Transactivation Cascade in Jurkat T Cells. J Biol Chem 276: 31627-31634.

Bluestone JA. 1995. New perspectives of CD28-B7-mediated $\mathrm{T}$ cell costimulation. Immunity 2: 555-559.

Boden E, Tang Q, Bour-Jordan H, Bluestone JA. 2003. The role of CD28 and CTLA4 in the function and homeostasis of CD $4+\mathrm{CD} 25+$ regulatory T cells. Novartis Found Symp 252: 55-63; discussion 63-56, 106-114.

Bohjanen PR, Petryniak B, June CH, Thompson CB, Lindsten T. 1992. AU RNA-binding factors differ in their binding specificities and affinities. J Biol Chem 267: 6302-6309.

Boise LH, Minn AJ, Noel PJ, June CH, Accavitti MA, Lindsten T, Thompson CB. 1995. CD28 costimulation can promote $\mathrm{T}$ cell survival by enhancing the expression of Bcl- $\mathrm{x}_{\mathrm{L}}$. Immunity 3: 87-98.

Bretscher P, Cohn M. 1970. A theory of self-nonself discrimination. Science 169: 1042-1049.

Bromley SK, Iaboni A, Davis SJ, Whitty A, Green JM, Shaw AS, Weiss A, Dustin ML. 2001. The immunological synapse and CD28-CD80 interactions. Nat Immunol 2: 1159-1166.

Bunnell SC, Hong DI, Kardon JR, Yamazaki T, McGlade CJ, Barr VA, Samelson LE. 2002. T cell receptor ligation induces the formation of dynamically regulated signaling assemblies. J Cell Biol 158: 1263-1275.

Burr JS, Kimzey SL, Randolph DR, Green JM. 2001a. CD28 and CTLA4 coordinately regulate airway inflammatory cell recruitment and T-helper cell differentiation after inhaled allergen. Am J Respir Cell Mol Biol 24: 563-568.

Burr JS, Savage NDL, Messah GE, Kimzey SL, Shaw AS, Arch RH, Green JM. 2001b. Cutting Edge: Distinct Motifs Within CD28 Regulate T Cell Proliferation and Induction of Bcl-XL. J Immunol 166: 5331-5335.

Bustelo XR. 2000. Regulatory and signaling properties of the Vav family. Mol Cell Biol 20: 1461-1477.

Cai YC, Cefai D, Schneider H, Raab M, Nabavi N, Rudd CE. 1995. Selective CD28pYMNM mutations implicate phosphatidylinositol 3-kinase in CD86-CD28-mediated costimulation. Immunity 3: 417-426.

Cefai D, Schneider H, Matangkasombut O, Kang H, Brody J, Rudd CE. 1998. CD28 receptor endocytosis is targeted by mutations that disrupt phosphatidylinositol 3-kinase binding and costimulation. J Immunol 160: 2223-2230.

Chen CY, Del Gatto-Konczak F, Wu Z, Karin M. 1998. Stabilization of interleukin-2 mRNA by the c-Jun NH2-terminal kinase pathway. Science 280: 1945-1949.

Chen CY, Gherzi R, Andersen JS, Gaietta G, Jurchott K, Royer HD, Mann M, Karin M. 2000. Nucleolin and YB-1 are required for JNK-mediated interleukin-2 mRNA stabilization during T-cell activation. Genes Dev 14: $1236-1248$.

Collins TL, Deckert M, Altman A. 1997. Views on Vav. Immunol Today 18: 221-225.

Corthesy B, Kao PN. 1994. Purification by DNA affinity chromatography of two polypeptides that contact the NF-AT DNA binding site in the interleukin 2 promoter. J Biol Chem 269: 20682-20690.

Costello PS, Gallagher M, Cantrell DA. 2002. Sustained and dynamic inositol lipid metabolism inside and outside the immunological synapse. Nat Immunol 3: 1082-1089.

Coudronniere N, Villalba M, Englund N, Altman A. 2000. NF- $\kappa$ B activation induced by $\mathrm{T}$ cell receptor/CD28 costimulation is mediated by protein kinase C- $\theta$. Proc Natl Acad Sci 97: 3394-3399.

Crooks ME, Littman DR, Carter RH, Fearon DT, Weiss A, Stein PH. 1995. CD28-mediated costimulation in the 
J.S. Boomer and J.M. Green

absence of phosphatidylinositol 3- kinase association and activation. Mol Cell Biol 15: 6820-6828.

Dahl AM, Klein C, Andres PG, London CA, Lodge MP, Mulligan RC, Abbas AK. 2000. Expression of Bcl-XL Restores Cell Survival, but Not Proliferation and Effector Differentiation, in CD28-deficient T Lymphocytes. J Exp Med 191: 2031-2038.

Damle NK, Doyle LV. 1989. Stimulation via the CD3 and CD28 molecules induces responsiveness to IL- 4 in CD4+CD29+CD45R- memory T lymphocytes. J Immunol 143: 1761-1767.

Damle NK, Doyle LV, Grosmaire LS, Ledbetter JA. 1988. Differential regulatory signals delivered by antibody binding to the CD28 (Tp44) molecule during the activation of human T lymphocytes. J Immunol 140: 1753-1761.

Dariavach P, Mattei MG, Golstein P, Lefranc MP. 1988 Human Ig superfamily CTLA-4 gene: Chromosomal localization and identity of protein sequence between murine and human CTLA-4 cytoplasmic domains. Eur J Immunol 18: 1901-1905.

Diehn M, Alizadeh AA, Rando OJ, Liu CL, Stankunas K, Botstein D, Crabtree GR, Brown PO. 2002. Genomic expression programs and the integration of the CD28 costimulatory signal in $\mathrm{T}$ cell activation. PNAS 99: 11796-11801.

Dienz O, Hehner SP, Droge W, Schmitz ML. 2000. Synergistic activation of NF- $\kappa$ B by functional cooperation between vav and PKC $\theta$ in T lymphocytes. J Biol Chem 275: 24547-24551.

Dodson LF, Boomer JS, Deppong CM, Shah DD, Sim J, Bricker TL, Russell JH, Green JM. 2009. Targeted knockin mice expressing mutations of CD28 reveal an essential pathway for costimulation. MCB 29: 3710-3721.

Dustin ML, Chan AC. 2000. Signaling takes shape in the immune system. Cell 103: 283-294.

Ellis JH, Ashman C, Burden MN, Kilpatrick KE, Morse MA, Hamblin PA. 2000. GRID: a novel Grb-2-related adapter protein that interacts with the activated T cell costimulatory receptor CD28. J Immunol 164: 5805-5814.

Evans EJ, Esnouf RM, Manso-Sancho R, Gilbert RJ, James JR, Yu C, Fennelly JA, Vowles C, Hanke T, Walse B et al. 2005. Crystal structure of a soluble CD28-Fab complex. Nat Immunol 6: 271-279.

Fang X, Yu S, Tanyi JL, Lu Y, Woodgett JR, Mills GB. 2002. Convergence of multiple signaling cascades at glycogen synthase kinase 3: Edg receptor-mediated phosphorylation and inactivation by lysophosphatidic acid through a protein kinase C-dependent intracellular pathway. Mol Cell Biol 22: 2099-2110.

Fischer KD, Tedford K, Penninger JM. 1998. Vav links antigen-receptor signaling to the actin cytoskeleton. Semin Immunol 10: 317-327.

Fraser JD, Irving BA, Crabtree GR, Weiss A. 1991. Regulation of interleukin-2 gene enhancer activity by the $\mathrm{T}$ cell accessory molecule CD28. Science 251: 313-316.

Frauwirth KA, Riley JL, Harris MH, Parry RV, Rathmell JC, Plas DR, Elstrom RL, June CH, Thompson CB. 2002. The CD28 signaling pathway regulates glucose metabolism. Immunity 16: 769-777.

Freeburn RW, Wright KL, Burgess SJ, Astoul E, Cantrell DA, Ward SG. 2002. Evidence that SHIP-1 contributes to phosphatidylinositol 3,4,5-trisphosphate metabolism in T lymphocytes and can regulate novel phosphoinositide 3-kinase effectors. J Immunol 169: 5441-5450.

Freeman GJ, Freedman AS, Segil JM, Lee G, Whitman JF, Nadler LM. 1989. B7, a new member of the Ig superfamily with unique expression on activated and neoplastic B cells. J Immunol 143: 2714-2722.

Freeman GJ, Gribben JG, Boussiotis VA, Ng JW, Restivo VAJr, Lombard LA, Gray GS, Nadler LM. 1993. Cloning of B7-2: A CTLA-4 counter-receptor that costimulates human T cell proliferation. Science 262: 909-911.

Freiberg BA, Kupfer H, Maslanik W, Delli J, Kappler J, Zaller DM, Kupfer A. 2002. Staging and resetting T cell activation in SMACs. Nat Immunol 3: 911-917.

Friend LD, Shah DD, Deppong C, Lin J, Bricker TL, Juehne TI, Rose CM, Green JM. 2006. A dose-dependent requirement for the proline motif of CD28 in cellular and humoral immunity revealed by a targeted knockin mutant. J Exp Med 203: 2121-2133.

Gaide O, Favier B, Legler DF, Bonnet D, Brissoni B, Valitutti S, Bron C, Tschopp J, Thome M. 2002. CARMA1 is a critical lipid raft-associated regulator of TCR-induced NF- $\mathrm{K}$ B activation. Nat Immunol 3: 836-843.

Garcon F, Patton DT, Emery JL, Hirsch E, Rottapel R, Sasaki T, Okkenhaug K. 2008. CD28 provides T-cell costimulation and enhances PI3K activity at the immune synapse independently of its capacity to interact with the p85/ p110 heterodimer. Blood 111: 1464-1471.

Genovese MC, Becker JC, Schiff M, Luggen M, Sherrer Y, Kremer J, Birbara C, Box J, Natarajan K, Nuamah I et al. 2005. Abatacept for rheumatoid arthritis refractory to tumor necrosis factor $\alpha$ inhibition. $N$ Engl $J$ Med 353: $1114-1123$.

Gmünder H, Lesslauer W. 1984. A 45-kDa human T-cell membrane glycoprotein functions in the regulation of cell proliferative responses. Eur J Biochem 142: 153-160.

Gogishvili T, Elias F, Emery JL, McPherson K, Okkenhaug K, Hunig T, Dennehy KM. 2008. Proliferative signals mediated by CD28 superagonists require the exchange factor Vav1 but not phosphoinositide 3-kinase in primary peripheral T cells. Eur J Immunol 38: 2528-2533.

Goode N, Hughes K, Woodgett JR, Parker PJ. 1992. Differential regulation of glycogen synthase kinase- $3 \beta$ by protein kinase C isotypes. J Biol Chem 267: 16878-16882.

Grakoui A, Bromley SK, Sumen C, Davis MM, Shaw AS, Allen PM, Dustin ML. 1999. The immunological synapse: A molecular machine controlling T cell activation. Science 285: 221-227.

Granelli-Piperno A, Nolan P. 1991. Nuclear transcription factors that bind to elements of the IL-2 promoter. Induction requirements in primary human T cells. J Immunol 147: 2734-2739.

Gross JA, St John T, Allison JP. 1990. The murine homologue of the T lymphocyte antigen CD28. Molecular cloning and cell surface expression. J Immunol 144: 3201-3210.

Guo F, Iclozan C, Suh WK, Anasetti C, Yu XZ. 2008. CD28 controls differentiation of regulatory $\mathrm{T}$ cells from naive CD4 T cells. J Immunol 181: 2285-2291.

Hansen JA, Martin PJ, Nowinski RC. 1980. Monoclonal antibodies identifying a novel T-cell antigen and Ia 
antigens of human lymphocytes. Immunogenetics $\mathbf{1 0}$ 247-260.

Hara H, Wada T, Bakal C, Kozieradzki I, Suzuki S, Suzuki N, Nghiem M, Griffiths EK, Krawczyk C, Bauer B et al. 2003. The MAGUK family protein CARD11 is essential for lymphocyte activation. Immunity 18: 763-775.

Harada Y, Tokushima M, Matsumoto Y, Ogawa S, Otsuka M, Hayashi K, Weiss BD, June CH, Abe R. 2001. Critical requirement for the membrane-proximal cytosolic tyrosine residue for CD28-mediated costimulation in vivo. J Immunol 166: 3797-3803.

Harhaj EW, Sun SC. 1998. IкB kinases serve as a target of CD28 signaling. J Biol Chem 273: 25185-25190.

Harhaj EW, Good L, Xiao G, Uhlik M, Cvijic ME, RiveraWalsh I, Sun SC. 2000. Somatic mutagenesis studies of NF-к B signaling in human T cells: Evidence for an essential role of IKK $\gamma$ in NF- $\gamma$ B activation by T-cell costimulatory signals and HTLV-I Tax protein. Oncogene 19: $1448-1456$.

Harhaj EW, Maggirwar SB, Good L, Sun SC. 1996. CD28 mediates a potent costimulatory signal for rapid degradation of $\mathrm{I} \gamma \mathrm{B} \beta$ which is associated with accelerated activation of various NF-кB/Rel heterodimers. Mol Cell Biol 16: $6736-6743$.

Harriague J, Bismuth G. 2002. Imaging antigen-induced PI3K activation in T cells. Nat Immunol 3: 1090-1096.

Harris N, Campbell C, Le Gros G, Ronchese F. 1997a. Blockade of CD28/B7 co-stimulation by mCTLA4-H 1 inhibits antigen- induced lung eosinophilia but not Th2 cell development or recruitment in the lung. Eur J Immunol 27: $155-161$.

Harris N, Peach R, Naemura J, Linsley PS, Le Gros G, Ronchese F. 1997b. CD80 costimulation is essential for the induction of airway eosinophilia. J Exp Med 185: 177182.

Hayashi K, Altman A. 2006. Filamin A is required for T cell activation mediated by protein kinase C- $\theta$. J Immunol 177: $1721-1728$.

Hehner SP, Hofmann TG, Dienz O, Droge W, Schmitz ML. 2000a. Tyrosine-phosphorylated Vav1 as a point of integration for T-cell receptor- and CD28-mediated activation of JNK, p38, and interleukin-2 transcription. J Biol Chem 275: 18160-18171.

Hehner SP, Hofmann TG, Ushmorov A, Dienz O, Wing-Lan Leung I, Lassam N, Scheidereit C, Droge W, Schmitz ML. 2000b. Mixed-lineage kinase 3 delivers CD3/CD28derived signals into the ІкВ kinase complex. Mol Cell Biol 20: 2556-2568.

Holdorf AD, Green JM, Levin SD, Denny MF, Straus DB, Link V, Changelian PS, Allen PM, Shaw AS. 1999. Proline residues in $\mathrm{CD} 28$ and the Src homology (SH) 3 domain of Lck are required for T cell costimulation. J Exp Med 190: 375-384.

Holsinger LJ, Graef IA, Swat W, Chi T, Bautista DM, Davidson L, Lewis RS, Alt FW, Crabtree GR. 1998. Defects in actin-cap formation in Vav-deficient mice implicate an actin requirement for lymphocyte signal transduction. Curr Biol 8: 563-572.

Howard TA, Rochelle JM, Seldin MF. 1991. Cd28 and Ctla-4, two related members of the Ig supergene family, are tightly linked on proximal mouse chromosome 1 . Immunogenetics 33: 74-76.
Huang J, Lo P-F, Zal T, Gascoigne NRJ, Smith BA, Levin SD, Grey HM. 2002. CD28 plays a critical role in the segregation of PKC $\theta$ within the immunologic synapse. PNAS 99: 9369-9373.

Hutchcroft JE, Bierer BE. 1994. Activation-dependent phosphorylation of the T-lymphocyte surface receptor CD28 and associated proteins. Proc Natl Acad Sci 91: $3260-3264$.

Hutchcroft JE, Tsai B, Bierer BE. 1996. Differential phosphorylation of the T lymphocyte costimulatory receptor CD28. Activation-dependent changes and regulation by protein kinase C. J Biol Chem 271: 13362-13370.

Hutloff A, Dittrich AM, Beier KC, Eljaschewitsch B, Kraft R, Anagnostopoulos I, Kroczek RA. 1999. ICOS is an inducible T-cell co-stimulator structurally and functionally related to CD28. Nature 397: 263-266.

Ishida Y, Agata Y, Shibahara K, Honjo T. 1992. Induced expression of PD-1, a novel member of the immunoglobulin gene superfamily, upon programmed cell death. Embo J 11: 3887-3895.

Jenkins MK, Chen CA, Jung G, Mueller DL, Schwartz RH. 1990. Inhibition of antigen-specific proliferation of type 1 murine $\mathrm{T}$ cell clones after stimulation with immobilized anti-CD3 monoclonal antibody. J Immunol 144: $16-22$.

Johnson KG, Bromley SK, Dustin ML, Thomas ML. 2000. A supramolecular basis for CD45 tyrosine phosphatase regulation in sustained T cell activation. Proc Natl Acad Sci 97: 10138-10143.

Jones RG, Elford AR, Parsons MJ, Wu L, Krawczyk CM, Yeh WC, Hakem R, Rottapel R, Woodgett JR, Ohashi PS 2002. CD28-dependent activation of protein kinase B/ Akt blocks Fas-mediated apoptosis by preventing death-inducing signaling complex assembly. J Exp Med 196: $335-348$.

Jones RG, Parsons M, Bonnard M, Chan VS, Yeh WC, Woodgett JR, Ohashi PS. 2000. Protein kinase B regulates T lymphocyte survival, nuclear factor $\mathrm{\kappa B}$ activation, and Bcl-X(L) levels in vivo. J Exp Med 191: 1721-1734.

Jun JE, Wilson LE, Vinuesa CG, Lesage S, Blery M, Miosge LA, Cook MC, Kucharska EM, Hara H, Penninger JM et al. 2003. Identifying the MAGUK protein Carma-1 as a central regulator of humoral immune responses and atopy by genome-wide mouse mutagenesis. Immunity 18: 751-762.

June CH, Bluestone JA, Nadler LM, Thompson CB. 1994. The $\mathrm{B} 7$ and $\mathrm{CD} 28$ receptor families. Immunol Today 15: 321-330.

June CH, Ledbetter JA, Linsley PS, Thompson CB. 1990. Role of the CD28 receptor in T-cell activation. Immunol Today 11: 211-216.

Kaga S, Ragg S, Rogers KA, Ochi A. 1998. Stimulation of CD28 with B7-2 promotes focal adhesion-like cell contacts where Rho family small $G$ proteins accumulate in T cells. J Immunol 160: 24-27.

Kane LP, Andres PG, Howland KC, Abbas AK, Weiss A. 2001. Akt provides the $\mathrm{CD} 28$ costimulatory signal for up-regulation of IL- 2 and IFN- $\gamma$ but not TH 2 cytokines. Nat Immunol 2: 37-44.

Kane LP, Shapiro VS, Stokoe D, Weiss A. 1999. Induction of NF-кB by the Akt/PKB kinase. Curr Biol 9: 601-604. 
J.S. Boomer and J.M. Green

Keane-Myers A, Gause WC, Linsley PS, Chen SJ, Wills-Karp M. 1997. B7-CD28/CTLA-4 costimulatory pathways are required for the development of $\mathrm{T}$ helper cell 2-mediated allergic airway responses to inhaled antigens. J Immunol 158: $2042-2049$.

Khoshnan A, Tindell C, Laux I, Bae D, Bennett B, Nel AE. 2000. The NF- $\kappa \mathrm{B}$ cascade is important in Bcl-xL expression and for the anti-apoptotic effects of the $\mathrm{CD} 28$ receptor in primary human CD4+ lymphocytes. J Immunol 165: $1743-1754$

Kim H-H, Tharayil M, Rudd CE. 1998. Growth factor receptor-bound protein $2 \mathrm{SH} 2 / \mathrm{SH} 3$ domain binding to CD28 and its role in co-signaling. J Biol Chem 273: 296-301.

King PD, Sadra A, Teng JM, Xiao-Rong L, Han A, Selvakumar A, August A, Dupont B. 1997. Analysis of CD28 cytoplasmic tail tyrosine residues as regulators and substrates for the protein tyrosine kinases, EMT and LCK. $J$ Immunol 158: 580-590.

King CL, Stupi RJ, Craighead N, June CH, Thyphronitis G. 1995. CD28 activation promotes Th2 subset differentiation by human CD4+ cells. Eur J Immunol 25: 587-595.

Kirchhoff S, Muller WW, Li-Weber M, Krammer PH. 2000. Up-regulation of c-FLIPshort and reduction of activation-induced cell death in CD28-costimulated human T cells. Eur J Immunol 30: 2765-2774.

Kobayashi K, Inohara N, Hernandez LD, Galan JE, Nunez G Janeway CA, Medzhitov R, Flavell RA. 2002. RICK/Rip2/ CARDIAK mediates signalling for receptors of the innate and adaptive immune systems. Nature 416: 194-199.

Krawczyk C, Oliveira-dos-Santos A, Sasaki T, Griffiths E, Ohashi PS, Snapper S, Alt F, Penninger JM. 2002. Vavl controls integrin clustering and MHC/peptide-specific cell adhesion to antigen-presenting cells. Immunity 16: 331-343.

Krummel MF, Sjaastad MD, Wulfing C, Davis MM. 2000. Differential clustering of CD4 and CD3zeta during T cell recognition. Science 289: 1349-1352.

Lafferty KJ, Cunningham AJ. 1975. A new analysis of allogeneic interactions. Aust J Exp Biol Med Sci 53: 27-42.

Lai JH, Tan TH. 1994. CD28 signaling causes a sustained down-regulation of I $\kappa$ B $\alpha$ which can be prevented by the immunosuppressant rapamycin. J Biol Chem 269: 30077-30080.

Larsen CP, Elwood ET, Alexander DZ, Ritchie SC, Hendrix R, Tucker-Burden C, Cho HR, Aruffo A, Hollenbaugh D, Linsley PS et al. 1996. Long-term acceptance of skin and cardiac allografts after blocking CD40 and CD28 pathways. Nature 381: 434-438.

Ledbetter JA, Imboden JB, Schieven GL, Grosmaire LS, Rabinovitch PS, Lindsten T, Thompson CB, June CH. 1990. CD28 ligation in T-cell activation: Evidence for two signal transduction pathways. Blood 75: 1531-1539.

Lee KY, D'Acquisto F, Hayden MS, Shim JH, Ghosh S. 2005 PDK1 nucleates T cell receptor-induced signaling complex for NF-кB activation. Science 308: 114-118.

Lee KP, Taylor C, Petryniak B, Turka LA, June CH, Thompson CB. 1990. The genomic organization of the CD28 gene. Implications for the regulation of CD28 mRNA expression and heterogeneity. J Immunol 145: 344-352.
Lenschow DJ, Herold KC, Rhee L, Patel B, Koons A, Kin H-Y, Fuchs E, Singh B, Thompson CB, Bluestone JA. 1996. CD28/B7 regulation of Th1 and Th2 subsets in the development of autoimmune diabetes. Immunity 5: 285-293.

Li Y, Sedwick CE, Hu J, Altman A. 2005. Role for protein kinase $\mathrm{C} \theta$ ( $\mathrm{PKC} \theta)$ in TCR/CD28-mediated signaling through the canonical but not the non-canonical pathway for NF-кB activation. J Biol Chem 280: 1217-1223.

Lin X, Cunningham ETJr, Mu Y, Geleziunas R, Greene WC. 1999. The proto-oncogene Cot kinase participates in $\mathrm{CD} 3 / \mathrm{CD} 28$ induction of NF- $\mathrm{KB}$ acting through the $\mathrm{NF}-\kappa \mathrm{B}$-inducing kinase and ІкB kinases. Immunity 10: 271-280.

Lindsten T, June CH, Ledbetter JA, Stella G, Thompson CB. 1989. Regulation of lymphokine messenger RNA stability by a surface-mediated T cell activation pathway. Science 244: $339-343$.

Linsley PS, Ledbetter JA. 1993. The role of the CD28 receptor during $\mathrm{T}$ cell responses to antigen. Annu Rev Immunol 11: 191-212.

Linsley PS, Nadler SG. 2009. The clinical utility of inhibiting CD28-mediated costimulation. Immunol Rev 229: 307-321.

Lohr J, Knoechel B, Kahn EC, Abbas AK. 2004. Role of B7 in T cell tolerance. J Immunol 173: 5028-5035.

Lu Y, Phillips CA, Trevillyan JM. 1995. Phosphatidylinositol 3-kinase activity is not essential for CD28 costimulatory activity in Jurkat T cells: Studies with a selective inhibitor, wortmannin. Eur J Immunol 25: 533-537.

Lucas PJ, Negishi I, Nakayama K, Fields LE, Loh DY. 1995. Naive CD28-deficient T cells can initiate but not sustain an in vitro antigen-specific immune response. J Immunol 154: $5757-5768$.

Luhder F, Huang Y, Dennehy KM, Guntermann C, Muller I, Winkler E, Kerkau T, Ikemizu S, Davis SJ, Hanke Tet al. 2003. Topological requirements and signaling properties of $\mathrm{T}$ cell-activating, anti-CD28 antibody superagonists. J Exp Med 197: 955-966.

Manicassamy S, Gupta S, Huang Z, Sun Z. 2006. Protein Kinase C- $\{\theta\}$-Mediated Signals Enhance CD4+ T Cell Survival by Up-Regulating Bcl-xL. J Immunol 176: 6709-6716.

Marengere LE, Okkenhaug K, Clavreul A, Couez D, Gibson S, Mills GB, Mak TW, Rottapel R. 1997. The SH3 domain of Itk/Emt binds to proline-rich sequences in the cytoplasmic domain of the $\mathrm{T}$ cell costimulatory receptor CD28. J Immunol 159: 3220-3229.

Marinari B, Costanzo A, Marzano V, Piccolella E, Tuosto L. 2004. CD28 delivers a unique signal leading to the selective recruitment of RelA and p52 NF- $\mathrm{\kappa B}$ subunits on IL-8 and Bcl-xL gene promoters. Proc Natl Acad Sci 101: 6098-6103.

Marinari B, Costanzo A, Viola A, Michel F, Mangino G, Acuto O, Levrero M, Piccolella E, Tuosto L. 2002. Vav cooperates with $\mathrm{CD} 28$ to induce NF- $\mathrm{\kappa B}$ activation via a pathway involving Rac-1 and mitogen-activated kinase kinase 1. Eur J Immunol 32: 447-456.

Mathur M, Herrmann K, Qin Y, Gulmen F, Li X, Krimins R, Weinstock J, Elliott D, Bluestone JA, Padrid P. 1999. CD28 interactions with either CD80 or CD86 are sufficient to induce allergic airway inflammation in mice. Am J Respir Cell Mol Biol 21: 498-509. 
Matsumoto R, Wang D, Blonska M, Li H, Kobayashi M, Pappu B, Chen Y, Lin X. 2005. Phosphorylation of CARMA1 plays a critical role in T Cell receptor-mediated NF- $\kappa$ B activation. Immunity 23: 575-585.

Michel F, Mangino G, Attal-Bonnefoy G, Tuosto L, Alcover A, Roumier A, Olive D, Acuto O. 2000. CD28 utilizes Vav-1 to enhance TCR-proximal signaling and NF-AT activation. J Immunol 165: 3820-3829.

Miller J, Baker C, Cook K, Graf B, Sanchez-Lockhart M, Sharp K, Wang X, Yang B, Yoshida T. 2009. Two pathways of costimulation through CD28. Immunol Res

Miller SD, Vanderlugt CL, Lenschow DJ, Pope JG, Karandikar NJ, Dal Canto MC, Bluestone JA. 1995. Blockade of CD28/B7-1 interaction prevents epitope spreading and clinical relapses of murine EAE. Immunity 3: 739-745.

Monks CR, Freiberg BA, Kupfer H, Sciaky N, Kupfer A. 1998. Three-dimensional segregation of supramolecular activation clusters in T cells. Nature 395: 82-86.

Mueller D, Jenkins MK, Schwartz RH. 1989. An accessory cell-derived costimulatory signal acts independently of protein kinase $\mathrm{C}$ activation to allow $\mathrm{T}$ cell proliferation and prevent the induction of unresponsiveness. J Immunol 142: 2617-2628.

Naluai AT, Nilsson S, Samuelsson L, Gudjonsdottir AH, Ascher H, Ek J, Hallberg B, Kristiansson B, Martinsson T, Nerman O et al. 2000. The CTLA4/CD28 gene region on chromosome 2q33 confers susceptibility to celiac disease in a way possibly distinct from that of type 1 diabetes and other chronic inflammatory disorders. Tissue Antigens 56: 350-355.

Nirula A, Ho M, Phee H, Roose J, Weiss A. 2006. Phosphoinositide-dependent kinase 1 targets protein kinase A in a pathway that regulates interleukin 4. J Exp Med 203: 1733-1744.

Noel PJ, Alegre ML, Reiner SL, Thompson CB. 1998. Impaired negative selection in CD28-deficient mice. Cell Immunol 187: 131-138.

Noel PJ, Boise LH, Green JM, Thompson CB. 1996. CD28 costimulation prevents cell death during primary $\mathrm{T}$ cell activation. J Immunol 157: 636-642.

Ogilvie RL, Abelson M, Hau HH, Vlasova I, Blackshear PJ, Bohjanen PR. 2005. Tristetraprolin down-regulates IL-2 gene expression through AU-rich element-mediated mRNA decay. J Immunol 174: 953-961.

Ohteki T, Parsons M, Zakarian A, Jones RG, Nguyen LT, Woodgett JR, Ohashi PS. 2000. Negative regulation of T cell proliferation and interleukin 2 production by the serine threonine kinase GSK-3. J Exp Med 192: 99-104.

Okkenhaug K, Rottapel R. 1998. Grb2 forms an inducible protein complex with CD28 through a Src homology 3 domain-proline interaction. J Biol Chem 273: $21194-$ 21202.

Okkenhaug K, Wu L, Garza KM, La Rose J, Khoo W, Odermatt B, Mak TW, Ohashi PS, Rottapel R. 2001. A point mutation in CD28 distinguishes proliferative signals from survival signals. Nat Immunol 2: 325-332.

Pagès F, Ragueneau M, Rottapel R, Truneh A, Nunes J, Imbert J, Olive D. 1994. Binding of phosphatidylinositol-3-OH kinase to CD28 is required for T- cell signalling. Nature 369: 327-329.
Pan M, Winslow MM, Chen L, Kuo A, Felsher D, Crabtree GR. 2007. Enhanced NFATc1 Nuclear Occupancy Causes T Cell Activation Independent of CD28 Costimulation. J Immunol 178: 4315-4321.

Parry RV, Olive D, Westwick J, Sansom DM, Ward SG. 1997a. Evidence that a kinase distinct from protein kinase $\mathrm{C}$ and phosphatidylinositol 3-kinase mediates ligationdependent serine/threonine phosphorylation of the Tlymphocyte co-stimulatory molecule CD28. Biochem J 326: $249-257$.

Parry RV, Reif K, Smith G, Sansom DM, Hemmings BA, Ward SG. 1997b. Ligation of the T cell co-stimulatory receptor CD28 activates the serine-threonine protein kinase protein kinase B. Eur J Immunol 27: 2495-2501.

Paterson AM, Vanguri VK, Sharpe AH. 2009. SnapShot: B7/ CD28 costimulation. Cell 137: 974-974 e971.

Podojil JR, Miller SD. 2009. Molecular mechanisms of T-cell receptor and costimulatory molecule ligation/blockade in autoimmune disease therapy. Immunol Rev 229: 337-355.

Prasad KV, Cai YC, Raab M, Duckworth B, Cantley L, Shoelson SE, Rudd CE. 1994. T-cell antigen CD28 interacts with the lipid kinase phosphatidylinositol 3-kinase by a cytoplasmic Tyr(P)-Met-Xaa-Met motif. Proc Natl Acad Sci 91: 2834-2838.

Quill H, Schwartz RH. 1987. Stimulation of normal inducer $\mathrm{T}$ cell clones with antigen presented by purified Ia molecules in planar lipid membranes: Specific induction of a long-lived state of proliferative nonresponsiveness. J Immunol 138: 3704-3712.

Raab M, Pfister S, Rudd CE. 2001. CD28 signaling via VAV/ SLP-76 adaptors: Regulation of cytokine transcription independent of TCR ligation. Immunity 15: 921-933.

Raab M, Cai YC, Bunnell SC, Heyeck SD, Berg LJ, Rudd CE. 1995. p56Lck and p59Fyn regulate CD28 binding to phosphatidylinositol 3- kinase, growth factor receptorbound protein GRB-2, and T cell-specific proteintyrosine kinase ITK: Implications for T-cell costimulation. Proc Natl Acad Sci 92: 8891-8895.

Radvanyi LG, Shi Y, Vaziri H, Sharma A, Dhala R, Mills GB, Miller RG. 1996. CD28 costimulation inhibits TCR-induced apoptosis during a primary $\mathrm{T}$ cell response. J Immunol 156: 1788-1798.

Reiter R, Pfeffer K. 2002. Impaired germinal centre formation and humoral immune response in the absence of CD28 and interleukin-4. Immunol 106: 222-228.

Riley JL, Mao M, Kobayashi S, Biery M, Burchard J, Cavet G, Gregson BP, June CH, Linsley PS. 2002. Modulation of TCR-induced transcriptional profiles by ligation of CD28, ICOS, and CTLA-4 receptors. Proc Natl Acad Sci 99: $11790-11795$.

Rudd CE, Schneider H. 2003. Unifying concepts in CD28, ICOS and CTLA4 co-receptor signalling. Nat Rev Immunol 3: 544-556.

Rudd CE, Taylor A, Schneider H. 2009. CD28 and CTLA-4 coreceptor expression and signal transduction. Immunol Rev 229: 12-26.

Rulifson IC, Sperling AI, Fields PE, Fitch FW, Bluestone JA. 1997. CD28 costimulation promotes the production of Th2 cytokines. J Immunol 158: 658-665. 
J.S. Boomer and J.M. Green

Sadra A, Cinek T, Arellano JL, Shi J, Truitt KE, Imboden JB. 1999. Identification of Tyrosine Phosphorylation Sites in the CD28 Cytoplasmic Domain and Their Role in the Costimulation of Jurkat $\mathrm{T}$ Cells. J Immunol 162: 1966-1973.

Salojin KV, Zhang J, Delovitch TL. 1999. TCR and CD28 are coupled via ZAP-70 to the activation of the Vav/Rac-1-/ PAK-1/p38 MAPK signaling pathway. J Immunol 163: 844-853.

Salomon B, Lenschow DJ, Rhee L, Ashourian N, Singh B, Sharpe A, Bluestone JA. 2000. B7/CD28 costimulation is essential for the homeostasis of the CD4+CD25+ immunoregulatory $\mathrm{T}$ cells that control autoimmune diabetes. Immunity 12: 431-440.

Sanchez-Lockhart M, Miller J. 2006. Engagement of CD28 Outside of the Immunological Synapse Results in Up-Regulation of IL-2 mRNA Stability but Not IL-2 Transcription. J Immunol 176: 4778-4784.

Sanchez-Lockhart M, Graf B, Miller J. 2008. Signals and sequences that control CD28 localization to the central region of the immunological synapse. J Immunol 181: 7639-7648.

Sanchez-Lockhart M, Marin E, Graf B, Abe R, Harada Y, Sedwick CE, Miller J. 2004. Cutting edge: CD28mediated transcriptional and posttranscriptional regulation of IL-2 expression are controlled through different signaling pathways. J Immunol 173: 7120-7124.

Sasaki T, Irie-Sasaki J, Jones RG, Oliveira-dos-Santos AJ, Stanford WL, Bolon B, Wakeham A, Itie A, Bouchard D, Kozieradzki I et al. 2000. Function of PI3K $\gamma$ in thymocyte development, $\mathrm{T}$ cell activation, and neutrophil migration. Science 287: 1040-1046.

Sayegh MH, Turka LA. 1998. The role of T-cell costimulatory activation pathways in transplant rejection. $N$ Engl J Med 338: 1813-1821.

Schneider H, Cai Y-C, Prasad KVS, Shoelson SE, Rudd CE. 1995a. T cell antigen CD28 binds to the GRB-2/SOS complex, regulators of p21ras. Eur J Immunol 25: 1044-1050.

Schneider H, Cai YC, Prasad KV, Shoelson SE, Rudd CE. 1995b. T cell antigen CD28 binds to the GRB-2/SOS complex, regulators of p21ras. Eur J Immunol 25: 1044-1050.

Schwartz RH, Mueller DL, Jenkins MK, Quill H. 1989. T-cell clonal anergy. Cold Spring Harb Symp Quant Biol 54: 605-610.

Seko Y, Azmi H, Fariss R, Ragheb JA. 2004. Selective cytoplasmic translocation of HuR and site-specific binding to the interleukin-2 mRNA are not sufficient for CD28-mediated stabilization of the mRNA. J Biol Chem 279: 33359-33367.

Shahinian A, Pfeffer K, Lee KP, Kundig TM, Kishihara K, Wakeham A, Kawai K, Ohashi PS, Thompson CB, Mak TW. 1993a. Differential T cell costimulatory requirements in CD28-deficient mice. Science 261: 609-612.

Shahinian A, Pfeffer K, Lee KP, Kündig TM, Kishihara K, Wakeham A, Kawai K, Ohashi PS, Thompson CB, Mak TW. 1993b. Differential T cell costimulatory requirements in CD28-deficient mice. Science 261: 609-612.

Shan X, Czar MJ, Bunnell SC, Liu P, Liu Y, Schwartzberg PL, Wange RL. 2000. Deficiency of PTEN in Jurkat T cells causes constitutive localization of Itk to the plasma membrane and hyperresponsiveness to CD3 stimulation. Mol Cell Biol 20: 6945-6957.

Shapiro VS, Truitt KE, Imboden JB, Weiss A. 1997. CD28 mediates transcriptional upregulation of the interleukin-2 (IL-2) promoter through a composite element containing the CD28RE and NF-IL-2B AP-1 sites. $\mathrm{Mol} \mathrm{Cel}$ Biol 17: 4051-4058.

Sharpe AH. 2009. Mechanisms of costimulation. Immunol Rev 229: 5-11.

Shi L, Godfrey WR, Lin J, Zhao G, Kao PN. 2007. NF90 regulates inducible IL-2 gene expression in T cells. $J$ Exp Med 204: 971-977.

Shim J, Lim H, R Yates J, Karin M. 2002. Nuclear export of NF90 is required for interleukin-2 mRNA stabilization. Mol Cell 10: 1331-1344.

Snapper SB, Rosen FS. 1999. The Wiskott-Aldrich syndrome protein (WASP): Roles in signaling and cytoskeletal organization. Annu Rev Immunol 17: 905-929.

Songyang Z, Shoelson SE, Chaudhuri M, Gish G, Pawson T, Haser WG, King F, Roberts T, Ratnofsky S, Lechleider RJ et al. 1993. SH2 domains recognize specific phosphopeptide sequences. Cell 72: 767-778.

Sperling AI, Auger JA, Ehst BD, Rulifson IC, Thompson CB, Bluestone JA. 1996. CD28/B7 interactions deliver a unique signal to naive $\mathrm{T}$ cells that regulates cell survival but not early proliferation. J Immunol 157: 3909-3917.

Stein PH, Fraser JD, Weiss A. 1994. The cytoplasmic domain of CD28 is both necessary and sufficient for costimulation of interleukin-2 secretion and association with phosphatidylinositol 3'-kinase. Mol Cell Biol 14: 3392-3402.

Su B, Jacinto E, Hibi M, Kallunki T, Karin M, Ben-Neriah Y. 1994. JNK is involved in signal integration during costimulation of T lymphocytes. Cell 77: 727-736.

Sun Z, Arendt CW, Ellmeier W, Schaeffer EM, Sunshine MJ, Gandhi L, Annes J, Petrzilka D, Kupfer A, Schwartzberg $\mathrm{PL}$ et al. 2000. PKC- $\theta$ is required for TCR-induced NF- $\kappa \mathrm{B}$ activation in mature but not immature T lymphocytes. Nature 404: 402-407.

Tacke M, Hanke G, Hanke T, Hunig T. 1997. CD28-mediated induction of proliferation in resting $\mathrm{T}$ cells in vitro and in vivo without engagement of the $\mathrm{T}$ cell receptor: Evidence for functionally distinct forms of CD28. Eur J Immunol 27: 239-247.

Tai X, Cowan M, Feigenbaum L, Singer A. 2005. CD28 costimulation of developing thymocytes induces Foxp3 expression and regulatory $\mathrm{T}$ cell differentiation independently of interleukin 2. Nat Immunol 6: 152-162.

Tai X, Van Laethem F, Sharpe AH, Singer A. 2007. Induction of autoimmune disease in CTLA-4-/- mice depends on a specific CD28 motif that is required for in vivo costimulation. Proc Natl Acad Sci 104: 13756-13761.

Takeda K, Harada Y, Watanabe R, Inutake Y, Ogawa S, Onuki K, Kagaya S, Tanabe K, Kishimoto H, Abe R. 2008. CD28 stimulation triggers NF- $\mathrm{KB}$ activation through the CARMA1-PKC $\theta-G r b 2 / G a d s$ axis. Int Immunol 20: 1507-1515.

Tang Q, Henriksen KJ, Boden EK, Tooley AJ, Ye J, Subudhi SK, Zheng XX, Strom TB, Bluestone JA. 2003. Cutting edge: CD28 controls peripheral homeostasis of CD4+ CD25+ regulatory T cells. J Immunol 171: 3348-3352. 
Tanner MJ, Hanel W, Gaffen SL, Lin X. 2007. CARMA1 coiled-coil domain is involved in the oligomerization and subcellular localization of CARMA1 and is required for $\mathrm{T}$ cell receptor-induced NF- $\mathrm{\kappa B}$ activation. J Biol Chem 282: 17141-17147.

Tao R, Wang L, Han R, Wang T, Ye Q, Honjo T, Murphy TL, Murphy KM, Hancock WW. 2005. Differential effects of $\mathrm{B}$ and T lymphocyte attenuator and programmed death-1 on acceptance of partially versus fully MHC-mismatched cardiac allografts. J Immunol 175: 5774-5782.

Tavano R, Contento RL, Baranda SJ, Soligo M, Tuosto L, Manes S, Viola A. 2006. CD28 interaction with filamin-A controls lipid raft accumulation at the T-cell immunological synapse. Nat Cell Biol 8: 1270-1276.

Tezuka K, Tsuji T, Hirano D, Tamatani T, Sakamaki K, Kobayashi Y, Kamada M. 2000. Identification and characterization of rat AILIM/ICOS, a novel T-cell costimulatory molecule, related to the CD28/CTLA4 family. Biochem Biophys Res Commun 276: 335-345.

Thompson CB, Lindsten T, Ledbetter JA, Kunkel SL, Young HA, Emerson SG, Leiden JM, June CH. 1989. CD28 activation pathway regulates the production of multiple T-cell-derived lymphokines/cytokines. Proc Natl Acad Sci 86: 1333-1337.

Truitt KE, Hicks CM, Imboden JB. 1994. Stimulation of CD28 triggers an association between CD28 and phosphatidylinositol 3-kinase in Jurkat T cells. J Exp Med 179: $1071-1076$.

Truitt KE, Nagel T, Suen LF, Imboden JB. 1996. Structural requirements for CD28-mediated costimulation of IL-2 production in Jurkat $\mathrm{T}$ cells. J Immunol 156: 4539-4541.

Tuosto L, Costanzo A, Guido F, Marinari B, Vossio S, Moretti F, Levrero M, Piccolella E. 2000. Mitogen-activated kinase kinase kinase 1 regulates $\mathrm{T}$ cell receptor- and CD28-mediated signaling events which lead to NF-кB activation. Eur J Immunol 30: 2445-2454.

Turka LA, Linsley PS, Lin H, Brady W, Leiden JM, Wei R-Q, Gibson ML, Zheng X-G, Myrdal S, Gordon D et al. 1992. T-cell activation by the CD28 ligand B7 is required for cardiac allograft rejection in vivo. Proc Natl Acad Sci 89: 11102-11105.

van der Merwe PA. 2002. Formation and function of the immunological synapse. Curr Opin Immunol 14: $293-298$.

van der Merwe PA, Bodian DL, Daenke S, Linsley P, Davis SJ. 1997. CD80 (B7-1) binds both CD28 and CTLA-4 with a low affinity and very fast kinetics. J Exp Med 185: 393-403.

Vanhaesebroeck B, Alessi DR. 2000. The PI3K-PDK1 connection: more than just a road to PKB. Biochem J 346: $561-576$.

Venuprasad K, Parab P, Prasad DV, Sharma S, Banerjee PR, Deshpande M, Mitra DK, Pal S, Bhadra R, Mitra D et al. 2001. Immunobiology of CD28 expression on human neutrophils. I. CD28 regulates neutrophil migration by modulating CXCR-1 expression. Eur J Immunol 31: $1536-1543$.

Vilimek D, Duronio V. 2006. Cytokine-stimulated phosphorylation of GSK-3 is primarily dependent upon PKCs, not PKB. Biochem Cell Biol 84: 20-29.
Villalba M, Coudronniere N, Deckert M, Teixeiro E, Mas P, Altman A. 2000a. A novel functional interaction between Vav and PKC $\theta$ is required for TCR-induced T cell activation. Immunity 12: 151-160.

Villalba M, Hernandez J, Deckert M, Tanaka Y, Altman A. 2000b. Vav modulation of the Ras/MEK/ERK signaling pathway plays a role in NFAT activation and CD69 up-regulation. Eur J Immunol 30: 1587-1596.

Villegas EN, Elloso MM, Reichmann G, Peach R, Hunter CA. 1999. Role of CD28 in the generation of effector and memory responses required for resistance to Toxoplasma gondii. J Immunol 163: 3344-3353.

Vincenti F, Larsen C, Durrbach A, Wekerle T, Nashan B, Blancho G, Lang P, Grinyo J, Halloran PF, Solez K et al. 2005. Costimulation blockade with belatacept in renal transplantation. N Engl J Med 353: 770-781.

Waldmann TA, Morris JC. 2006. Development of antibodies and chimeric molecules for cancer immunotherapy. $A d v$ Immunol 90: 83-131.

Wang H, Rudd CE. 2008. SKAP-55, SKAP-55-related and ADAP adaptors modulate integrin-mediated immunecell adhesion. Trends Cell Biol 18: 486-493.

Wang D, Matsumoto R, You Y, Che T, Lin XY, Gaffen SL, Lin X. 2004. CD3/CD28 costimulation-induced NFactivation is mediated by recruitment of protein kinase $\mathrm{C}-\theta$, Bcl10, and ІкB kinase $\beta$ to the immunological synapse through CARMA1. Mol Cell Biol 24: 164-171.

Wang D, You Y, Case SM, McAllister-Lucas LM, Wang L, DiStefano PS, Nunez G, Bertin J, Lin X. 2002. A requirement for CARMA1 in TCR-induced NF- $\kappa$ B activation. Nat Immunol 3: 830-835.

Watanabe N, Gavrieli M, Sedy JR, Yang J, Fallarino F, Loftin SK, Hurchla MA, Zimmerman N, Sim J, Zang X et al. 2003. BTLA is a lymphocyte inhibitory receptor with similarities to CTLA-4 and PD-1. Nat Immunol 4: 670-679.

Watanabe R, Harada Y, Takeda K, Takahashi J, Ohnuki K, Ogawa S, Ohgai D, Kaibara N, Koiwai O, Tanabe K et al. 2006. Grb2 and Gads exhibit different interactions with CD28 and play distinct roles in CD28-mediated costimulation. J Immunol 177: 1085-1091.

Williams JA, Lumsden JM, Yu X, Feigenbaum L, Zhang J, Steinberg SM, Hodes RJ. 2008. Regulation of thymic NKT cell development by the B7-CD28 costimulatory pathway. J Immunol 181: 907-917.

Winzen R, Kracht M, Ritter B, Wilhelm A, Chen CY, Shyu AB, Muller M, Gaestel M, Resch K, Holtmann H. 1999. The p38 MAP kinase pathway signals for cytokineinduced mRNA stabilization via MAP kinase-activated protein kinase 2 and an AU-rich region-targeted mechanism. Embo J 18: 4969-4980.

Woerly G, Lacy P, Younes AB, Roger N, Loiseau S, Moqbel R, Capron M. 2002. Human eosinophils express and release IL-13 following CD28-dependent activation. J Leukoc Biol 72: 769-779.

Wood JE, Schneider H, Rudd CE. 2006. TcR and TcR-CD28 Engagement of Protein Kinase B (PKB/AKT) and Glycogen Synthase Kinase-3 (GSK-3) Operates Independently of Guanine Nucleotide Exchange Factor VAV-1. J Biol Chem 281: 32385-32394. 


\section{J.S. Boomer and J.M. Green}

Yamada T, Mitani T, Yorita K, Uchida D, Matsushima A, Iwamasa K, Fujita S, Matsumoto M. 2000. Abnormal immune function of hemopoietic cells from alymphoplasia (aly) mice, a natural strain with mutant NF-к Binducing kinase. J Immunol 165: 804-812.

Yokosuka T, Kobayashi W, Sakata-Sogawa K, Takamatsu M, Hashimoto-Tane A, Dustin ML, Tokunaga M, Saito T. 2008. Spatiotemporal regulation of $\mathrm{T}$ cell costimulation by TCR-CD28 microclusters and protein kinase C $\theta$ translocation. Immunity 29: 589-601.

Zhou XY, Yashiro-Ohtani Y, Nakahira M, Park WR, Abe R, Hamaoka T, Naramura M, Gu H, Fujiwara H. 2002. Molecular mechanisms underlying differential contribution of CD28 versus non-CD28 costimulatory molecules to IL-2 promoter activation. J Immunol 168: $3847-3854$. 


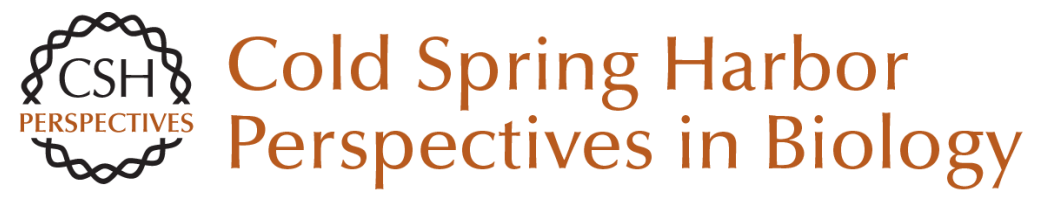

\section{An Enigmatic Tail of CD28 Signaling}

Jonathan S. Boomer and Jonathan M. Green

Cold Spring Harb Perspect Biol 2010; doi: 10.1101/cshperspect.a002436 originally published online June 9, 2010

\section{Subject Collection Immunoreceptor Signaling}

The Coordination of T-cell Function by Serine/Threonine Kinases

David Finlay and Doreen Cantrell

ITAM-mediated Signaling by the T-Cell Antigen Receptor

Paul E. Love and Sandra M. Hayes

Coordination of Receptor Signaling in Multiple Hematopoietic Cell Lineages by the Adaptor

Protein SLP-76

Martha S. Jordan and Gary A. Koretzky

The Cytoskeleton Coordinates the Early Events of B-cell Activation

Naomi E. Harwood and Facundo D. Batista

An Enigmatic Tail of CD28 Signaling

Jonathan S. Boomer and Jonathan M. Green

\section{Mediation of T-Cell Activation by Actin Meshworks \\ Peter Beemiller and Matthew F. Krummel}

T-Cell Signaling Regulated by the Tec Family

Kinase, Itk

Amy H. Andreotti, Pamela L. Schwartzberg, Raji E. Joseph, et al.
Perspectives for Computer Modeling in the Study of $\mathrm{T}$ Cell Activation Jesse Coward, Ronald N. Germain and Grégoire Altan-Bonnet

Structural Biology of the T-cell Receptor: Insights into Receptor Assembly, Ligand Recognition, and Initiation of Signaling

Kai W. Wucherpfennig, Etienne Gagnon, Melissa J. Call, et al.

Src-family and Syk Kinases in Activating and

Inhibitory Pathways in Innate Immune Cells:

Signaling Cross Talk Clifford A. Lowell

The LAT Story: A Tale of Cooperativity, Coordination, and Choreography

Lakshmi Balagopalan, Nathan P. Coussens, Eilon Sherman, et al.

Antigen Receptor Signaling to NF- $\mathrm{KB}$ via CARMA1, BCL10, and MALT1 Margot Thome, Jean Enno Charton, Christiane Pelzer, et al.

It's All About Change: The Antigen-driven Initiation of B-Cell Receptor Signaling Wanli Liu, Hae Won Sohn, Pavel Tolar, et al.

ZAP-70: An Essential Kinase in T-cell Signaling Haopeng Wang, Theresa A. Kadlecek, Byron B. Au-Yeung, et al.

For additional articles in this collection, see http://cshperspectives.cshlp.org/cgi/collection/

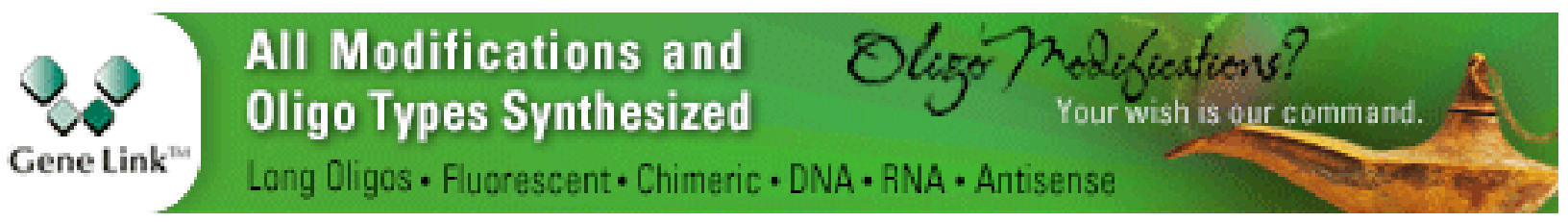




\section{Lipid Signaling in T-Cell Development and Function \\ Yina H. Huang and Karsten Sauer}

Understanding the Structure and Function of the Immunological Synapse

Michael L. Dustin, Arup K. Chakraborty and Andrey S. Shaw

For additional articles in this collection, see http://cshperspectives.cshlp.org/cgi/collection/

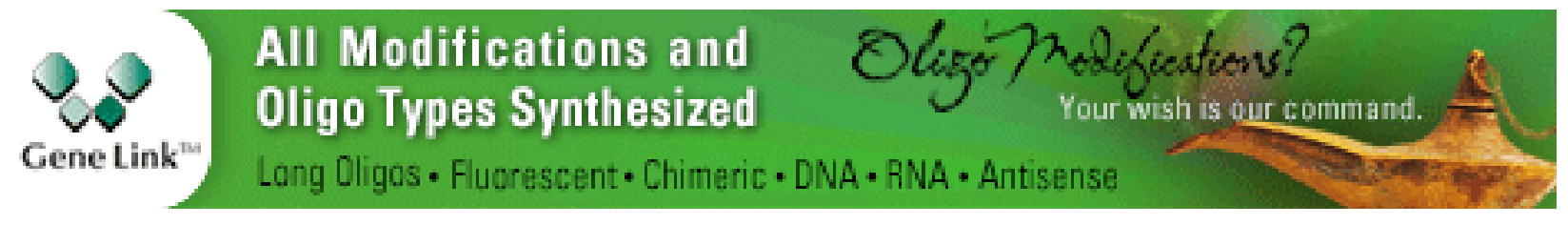

Copyright @ 2010 Cold Spring Harbor Laboratory Press; all rights reserved 